\title{
CAPITAL TAX REFORM AND THE REAL ECONOMY: THE EFFECTS OF THE 2003 DIVIDEND TAX CUT
}

\author{
Danny Yagan
}

\author{
ONLINE APPENDIX
}

\section{Online Appendix A: Variable Definitions in Terms of Tax Return Line Items}

Section II.C listed economic definitions of all variables used in this paper. This appendix defines variables in terms of line items on tax forms.

Investment equals the sum of Form 4562 lines 8, 14, 19a-19i column (c), 20a-20c column (c), and 21. Form 4562 is filed alongside either Form 1120 or Form 1120S in order to claim investment depreciation deductions.

Tangible capital assets is reported on Form 1120 or Form 1120S Schedule L (balance sheet) column (d) line 10b. ${ }^{58}$

For C-corporations, employee compensation equals the sum of Form 1120 lines 13, 23, 24, and Schedule A line 3. For S-corporations, employee compensation equals Form 1120S lines 8, 17, 18, and Schedule A line 3.

For C-corporations, dividends equals the sum of Form 1120 Schedule M-2 lines 5a and 5c. For S-corporations, dividends equals Form 1120S Schedule K line 17c. These fields are sources of NIPA dividend aggregates.

Treasury stock is reported on Form 1120 Schedule L column (d) line 27 for C-corporations or on Form 1120S Schedule L column (d) line 26 for S-corporations.

Total paid in capital equals the sum of the equity capital stock and additional paid-in capital. Equity capital stock is reported on Form 1120 Schedule L column (d) line 22b for C-corporations and Form 1120S Schedule L column (d) line 22 for S-corporations. Additional paid-in capital is reported on Form 1120 and Form 1120S Schedule L line 23. Note that these equity valuations are book concepts.

Assets is reported on Form 1120 and Form 1120S Schedule L column (d) line 15 and includes financial assets (e.g. cash), inventories, tangible assets (e.g. investment purchases), and intangible assets (e.g. goodwill).

Revenue equals operating revenue and is reported on Form 1120 and Form 1120S line 1c; this excludes non-operating income such as gains from selling used capital goods.

Profit margin is the ratio of operating profit to revenue. For C-corporations, operating profit equals the sum of Form 1120 lines 1c, 12, 18, 19, 20, and 25, minus the sum of lines 2 and 27. For S-corporations, operating profit equals the sum of Form 1120S lines 1c, 7, 13, and 14, minus the sum of lines 2 and 20.

\footnotetext{
${ }^{58}$ This excludes passive securities, inventories, depletable assets (e.g. oil deposits), land, and non-depreciable intangible assets (e.g. goodwill). Tangible capital assets is computed according to standard book accounting practices and equals the purchase price of all investment goods currently in use by the corporation, less accumulated book depreciation (as opposed to accumulated tax depreciation, which is affected by temporary accelerated depreciation).
} 
Cash equals the sum of column (d) lines 1, 4, 5, and 6 on Schedule L of Form 1120 or Form 1120 S.

Debt equals the sum of column (d) lines 16-21 on Schedule L of Form 1120 or Form 1120S. NAICS is reported on Form 1120 Schedule K line 2a and Form 1120S Schedule B line 2a. ${ }^{59}$ For C-corporations, incorporation date is reported on Form 1120 Box C. For S-corporations, incorporation date is reported on Form 1120S Box E.

\footnotetext{
${ }^{59}$ Corporations whose closest return to 2003 was filed before 1999 have 4-digit SIC classifications rather than 6-digit NAICS; I impute a 6-digit NAICS to each 4-digit SIC using the universe of corporations that filed tax returns in both 1998 and 1999 and use the first two digits of this imputed 6-digit NAICS for 2-digit NAICS.
} 


\section{Online Appendix B: Reweighting}

Section II.E verbally described the application of the reweighting method of DiNardo, Fortin, and Lemieux (DFL 1996) to flexibly control for any time-varying industry-firm-size shocks. DFL-reweighting is similar to matching but is less parametric. As mentioned in that section, this reweighting does not drive the paper's main results. This appendix specifies the formula for the final weight on every observation used in every table and graph.

DFL reweighting is useful when comparing outcomes across groups $g$ (e.g. corporation types and years) that differ along observable traits (e.g. the S-corporation sample has a larger share of big construction firms than the C-corporation sample). One wants to reweight the sample to hold "fixed" the distribution of observable traits across groups. To do so, one first divides all observations into bins $b$ according to the traits (e.g. small construction firms, big construction firms, etc.). Then one inflates or deflates weights in every group-bin so that the within-group distribution of weights across bins equals the original cross-bin distribution of weights in some base group $g$ (e.g. C-corporations in 2002). For example, if the 1998 S-corporation group has relatively more big construction firms than the 2002 C-corporation group, then the DFL procedure will down-weight big construction firms and up-weight small construction firms in the 1998 S-corporation group. In this way, DFL holds fixed the distribution of observable traits across groups.

This paper's main analyses (Figure 2, Table 2, and all appendix tables) compare outcomes across corporation types and time, so I DFL-reweight across $22(=2$ corporation types $\times 11$ years 1998-2008) groups $g$. I define the base group $g$ to be the 2002 C-corporation group. I implement DFL-reweighting to control for any industry and firm-size differences; I therefore use each observation's two-digit industry and firm size (revenue averaged over the preceding two lags) to bin it into one of 190 (= 19 two-digit industries $\times 10$ within-industry size deciles) bins $b$, where the bins are defined using the within-industry size deciles of $2002 \mathrm{C}$-corporations. Recall that in order to make the results dollar-weighted, each observation is initially weighted by its firm size (revenue averaged over the preceding two lags); let size $_{j}$ denote note this initial weight on firm-year observation $j$. Let $b$ denote the bin and let $g$ denote the group that observation $j$ falls in. The final weight $w$ on observation $j$ equals:

$$
w_{j b g}=\operatorname{size}_{j}\left(\frac{\sum_{j^{\prime} \in b \cap j^{\prime} \in \underline{g}} s i z e_{j^{\prime}}}{\sum_{j^{\prime} \in b \cap j^{\prime} \in g} s_{i z e_{j^{\prime}}}}\right)\left(\frac{\sum_{j^{\prime} \in g} s i z e_{j^{\prime}}}{\sum_{j^{\prime} \in \underline{g}} s_{z e_{j^{\prime}}}}\right)
$$

where $j^{\prime}$ denotes firm-year observations generally.

To explain the formula, note that the two parenthetical factors each equal 1 for every observation $j$ that is in the base group $g$, so every observation in the base group has final weight equal to its size $s_{i z e_{j}}$. Every observation not in the base group has final weight that is smaller or greater than its size, depending on whether its bin is overrepresented or underrepresented in its group relative to the base group. The first parenthetical factor is the key factor: it ensures that within every group $g$, the ratio of the sum of final weights in an industry-size bin $b$ (e.g. top-decile construction firms) to the sum of final weights in any other industry size bin $b^{\prime}$ (e.g. bottom-decile construction firms) is identical to the corresponding ratio in the base group $g$. The second factor ensures that the sum of each group's final weight equals the sum of that group's original weight (i.e. $\sum_{j^{\prime} \in g} w_{j^{\prime} b g}=\sum_{j^{\prime} \in g} s i z e_{j^{\prime}}, \forall g$ ); without this factor, the procedure would impose that the sum of each group's final weight equals the sum of the base group's 
original weight (i.e. $\sum_{j^{\prime} \in g} w_{j^{\prime} b g}=\sum_{j^{\prime} \in \underline{g}}$ size $_{j^{\prime}}, \forall g$ ) regardless of the relative size of that group's observations in the raw data.

This paper's main heterogeneity analysis (Table 3) reports coefficients from triple-difference regressions between corporation types (C vs. S), time period (pre-2003 vs. post-2003), and firm trait rank (top quintile vs. bottom quintile). Hence for the regressions underlying this table, I construct weights using equation (4) in which groups $g$ denote one of 44 type-year-trait groups (one for each corporation type, year 1998-2008, and top or bottom quintile), base group $\underline{g}$ denotes 2002 top-quintile C-corporations, and industry-size bins $b$ are defined according to the within-industry size-decile distribution of top-trait-quintile C-corporations in $2002{ }^{60}$

Finally, this paper's detailed firm size heterogeneity analysis (Figure 3) reports coefficients from difference-in-differences regressions within each firm size decile. Thus for the regressions underlying these graphs, I construct weights using equation (4) in which groups $g$ denote one of 220 type-year-decile groups $(=2$ corporation types $\times 11$ years $1998-2008 \times 10$ firm size deciles where the deciles are defined over the pooled C-corporation sample), base group $\underline{g}$ denotes 2002 fifth-decile C-corporations, and bins $b$ denote one of 19 two-digit industries. Corporations are unweighted in Table 1, Figure 1, and Appendix Figure 1.

\footnotetext{
${ }^{60}$ The exceptions are the triple-difference regressions by firm size, which can be reweighted only across 19 industry bins since the top and bottom firm size quintiles of course do not overlap.
} 


\section{Online Appendix C: Additional Robustness Checks (results reported in Online Appendix Tables 4-5)}

Online Appendix Tables 1-3 and 7 replicate the paper's primary results (reported in Table 2) across four alternative sample frames, variable definitions, and specifications: allowing for differential pre-2003 trends, scaling by lagged revenue instead of lagged tangible capital or vice versa, restricting the analysis to years 1998-2004 only, and including all public corporations that satisfy the paper's sample restrictions other than being privately held, respectively. Those robustness checks are detailed in the text in Section III.B and III.F and in the notes to those tables.

Online Appendix Tables 4-5 report results for additional robustness checks for the paper's main specification. This appendix supplements the details listed in those tables' notes.

\section{(C.i) Online Appendix Table 4}

The paper's main specification is equation (1) estimated in the main analysis sample with the paper's standard set of controls: year fixed effects, indicators for two-digit NAICS industry classification, and quartics in age, lagged revenue, lagged profit margin, and revenue growth from the second to the first lag. The estimated effect of the 2003 dividend tax cut on corporate investment in this main specification is reported in Table 2 column 2. For easy reference, Online Appendix Table 4 column 1 reprints Table 2 column 2.

Some corporations have foreign operations that yield special tax treatment. Online Appendix Table 4 column 2 repeats the main specification on the main analysis sample excluding corporations with an indication of foreign operations, defined as listing a positive foreign tax credit on its $t-2$ tax return (Form 1120 Schedule J line 5a or Form 1120S Schedule K line 14l).

Some corporations, especially those managed directly by a small number of owners, may relabel corporate income as officer bonuses, changing the tax treatment of that income. Column 3 repeats the main specification on the main analysis sample excluding corporations with high officer compensation, defined as having a top-quintile value of officer compensation to revenue in year $t-2$ following quintile definitions used in Section III.D.

The Tax Reform Act of 1986 altered incentives to operate as an S-corporation relative to a C-corporation. Column 4 repeats the main specification on the main analysis sample excluding corporations with an incorporation date lying before 1986 .

Because there are few extremely large S-corporations and all S-corporations are privately held, the main analysis sample excludes corporations with lagged assets greater than $\$ 1$ billion (or lagged revenue greater than $\$ 1.5$ billion) and corporations that were ever publicly held through the previous year. Column 5 repeats the main specification on an analysis sample that applies no lagged asset or lagged revenue upper bound and applies no privately-held restriction and thus includes all public corporations that could be matched to the SOI data and survive the remaining sample restrictions.

Dividend-paying C-corporations may be expected to respond differently from non-dividendpaying C-corporations. Column 6 repeats the main specification on the main analysis sample restricted to dividend-paying corporations, defined as those with a positive dividend in year $t-2$.

Young corporations may be expected to respond differently from older corporations, for example if they are less able than older corporations to fund profitable investments using retained earnings (see Section V for theoretical motivation). Column 7 repeats the main specification on the main analysis sample restricted to young corporations, defined as those with bottom-quintile 
age following quintile definitions used in Section III.D.

Salinger and Summers (1983) argued that firm capital stocks estimated using recursions on investment flows are superior to annually reported capital stocks, and some influential subsequent papers (e.g. Cummins, Hassett, and Hubbard 1994; Desai and Goolsbee 2004) scale investment by such estimated capital stocks in their empirical analyses. Column 8 repeats the main specification on the main analysis sample except that the dependent variable (investment) is scaled by lagged Salinger-Summers-estimated capital stocks rather than lagged tangible capital. To compute Salinger-Summers-estimated capital stocks, I follow Cummins, Hassett, and Hubbard (documented in their Appendix B) and Desai and Goolsbee (documented in their Appendix A) by estimating the declining balance depreciation rate that is consistent with each firm's initial and terminal reported tangible capital assets under perpetual inventory accounting. Specifically for each firm $i$, I solve for $\delta_{i}$ in the non-linear equation:

$$
K_{i T}=K_{i 0}\left(1-\delta_{i}\right)^{T}+I_{i 1}\left(1-\delta_{i}\right)^{T-1}+\ldots+I_{i, T-1}\left(1-\delta_{i}\right)+I_{i T}
$$

where $K_{i t}$ denotes tangible capital assets for firm $i$ in year $t$ and where year 0 corresponds to the first year and year $T$ corresponds to the last year observed in the SOI data for firm $i$ in years 1996$2008 .{ }^{61}$ Then for each firm, I use the estimated $\hat{\delta}_{i}$, actual annual values of investment $I_{i t}$, and actual initial and terminal values of tangible capital assets $K_{i 0}$ and $K_{i T}$ to estimate intermediate tangible capital assets $\hat{K}_{i 1}, \ldots, \hat{K}_{i, T-1}$. I then compute lagged tangible capital assets for each firm-year observation as in the main sample, using this estimated path of tangible capital assets $K_{i 0}, \hat{K}_{i 1}, \ldots, \hat{K}_{i, T-1}, K_{i T}$ rather than the actual reported path $K_{i 0}, K_{i 1}, \ldots, K_{i, T-1}, K_{i T}$ from the firm's annual balance sheet.

The DFL-reweighting used in the main specification controls non-parametrically for differences across C- and S-corporations along two dimensions known to predict investment behavior: firm size and industry. Propensity-score matching is a more-parametric and less-datademanding weighting technique that permits flexible reweighting along many dimensions known to predict investment behavior. Column 9 repeats the main specification on the main analysis sample with propensity-score matching following Dehejia and Wahba (2002) instead of DFL reweighting.

Specifically, I implement a version of the caliper matching utilized in Dehejia and Wahba (2002) that permits easy comparison to this paper's DFL weights and maintains the dollarweighting described in Online Appendix A. Specifically within each year, I estimate a probit regression of the C-corporation indicator on quartics in the six traits used in Table 3-lagged revenue, age, lagged revenue growth, lagged profitability, lagged cash as a fraction of lagged total assets, and lagged leverage - along with two-digit industry and year fixed effects and use the resulting coefficients to construct a propensity score for each firm equal to the estimated probability that the firm is in the treatment group (i.e. is a C-corporation) based on those controls. Let bin $b_{t}$ denote the decile of the firm-year's propensity score, where each bin $b_{t} \in\{1,2, \ldots, 10\}$ comprises firm-year observations with a propensity score in the range $[b / 10-$ $.1, b / 10]$. I then up-weight or down-weight S-corporations within each bin $b_{t}$ so that the sum of final S-corporation weights in any bin $b_{t}$ equals the sum of final C-corporation weights in that bin. For comparability to the final weights detailed in Online Appendix A, let group

\footnotetext{
${ }^{61} \mathrm{~A}$ solution to the non-linear equation was found for $99.9 \%$ of firms; the remaining $0.1 \%$ are excluded from the regression underlying column 8 . For the few instances in which a single firm appears in multiple non-contiguous sets of years 1996-2008, I estimate a separate depreciation rate for each set.
} 
marker $g$ equal the C-corporation indicator, and let $g$ denote C-corporations. Then the final propensity-score weight $w$ on firm-year observation $j$ equals:

$$
w_{j b_{t} g}=\operatorname{size}_{j}\left(\frac{\sum_{j^{\prime} \in b_{t} \cap j^{\prime} \in \underline{g}} s_{i z e_{j^{\prime}}}}{\sum_{j^{\prime} \in b_{t} \cap j^{\prime} \in g} s i z e_{j^{\prime}}}\right)\left(\frac{\sum_{j^{\prime} \in g} s i z e_{j^{\prime}}}{\sum_{j^{\prime} \in \underline{g}} s i z e_{j^{\prime}}}\right)
$$

Comparison of this equation to the equation (4) shows that these propensity-score weights differ from the DFL weights in that more traits than just size and industry are used to construct the bins $b$. To ensure overlap within each propensity-score bin, I set to missing any observations $j b_{t} g$ with no corresponding observations $j^{\prime} b_{t} g^{\prime}$ for $j \neq j^{\prime}$ and $g \neq g^{\prime}$; this sets only nine observations to missing.

Finally and in a related vein, column 10 repeats the main specification on the main analysis sample with no reweighting (i.e. with weight $w_{j}=s i z e_{j}, \forall j$ ). All specifications continue to yield statistically insignificant estimates of the effect of the 2003 dividend tax cut on C-corporation investment, except for one that yields a marginally significant negative estimate.

(C.ii) Online Appendix Table 5

The paper's main specification (equation 1) follows the investment literature by scaling annual investment by lagged (averaged over the previous two years) tangible capital assets. If C-corporations immediately adjusted to a higher steady state capital stock by making very large investments in 2003, investment divided by lagged tangible capital would not be elevated after 2004 when lagged capital would equal the new steady state - driving estimated effects of the dividend tax cut on investment toward zero by construction. ${ }^{62}$ In practice, C-corporation investment was unusually low immediately after the tax cut (see Online Appendix Table 3) and adjustment to new steady state capital stocks appears to take years due to adjustment costs (e.g. Auerbach and Hassett 1992). I nevertheless address such concerns in Online Appendix Table 5 by repeating the paper's main specification when scaling investment by time-invariant pre-2003 measures of firm capital stocks.

Columns 2-6 repeat the paper's main specification on the main analysis sample, restricted to "firm-era" observations (i.e. either the pre-2003 era or the post-2003 era) on firms that are in my sample for a specific number of years around 2003 and computing investment as average annual investment divided by pre-2003 lagged tangible capital. Specifically, each column corresponds to a year radius $S \in\{1,2,3,4,5\}$. For a given radius $S$, I restrict the pre-2003 subset of the main analysis sample to firms with observations in all years [2003 - S, 2002] and restrict the 2003-and-beyond subset to firms with observations in all years $[2003,2002+S]$. I then estimate equation (1) at the firm-era level in which the scaled investment dependent variable for firm $i$ in era $E \in\{0,1\}$ (referring to the pre-2003 era or the 2003-and-beyond era, respectively) equals the firm's average annual investment in the era divided by the earliest lagged capital value in

\footnotetext{
${ }^{62}$ In steady state with no technology growth, investment divided by lagged capital equals the depreciation rate; taxes and other prices affect only the scale of the steady state.
} 
the era in this subset:

$$
\begin{aligned}
\text { INVESTMENT } & =\frac{\frac{1}{S} \sum_{s=1}^{S} I_{i, 2003-s}}{\frac{1}{2}\left(K_{i, 2001-S}+K_{i, 2002-S}\right)} \\
\text { INVESTMENT }_{i 1} & =\frac{\frac{1}{S} \sum_{s=1}^{S} I_{i, 2003+s}}{\frac{1}{2}\left(K_{i, 2001}+K_{i, 2002}\right)}
\end{aligned}
$$

where $I_{i t}$ and $K_{i t}$ denote the firm's investment and tangible capital assets in year $t$, respectively. $^{63}$

For example, consider column 4 , which uses radius $S=3$. I restrict the pre-2003 subset of the main analysis sample to firms with observations in all years 2000-2002, and I restrict the 2003and-beyond subset to firms with observations in all years 2003-2005. I then condense pre-2003 observations to one observation per firm with INVESTMENT $T_{i 0}=\left[\left(I_{i 2000}+I_{i 2001}+I_{i 2002}\right) / 3\right] /$ $\left[\left(K_{i 1998}+K_{i 1999}\right) / 2\right]$ and condense post-2003 observations to one observation per firm with $I N V E S T M E N T_{i 1}=\left[\left(I_{i 2003}+I_{i 2004}+I_{i 2005}\right) / 3\right] /\left[\left(K_{i 2001}+K_{i 2002}\right) / 2\right]$. Because these specifications scale annual investment by pre-2003 measures of the firm's capital, any post-2003 increases in investment are not reflected in larger denominators. Relative to the paper's main result (reprinted in column 1), columns 2-6 report typically more negative and insignificant effects of the 2003 dividend tax cut on C-corporation investment.

\footnotetext{
${ }^{63}$ This differs from the firm-year observations in the main analysis sample in which $I N V E S T M E N T_{i t}=$ $I_{i t} /\left[\left(K_{i, t-1}+K_{i, t-2}\right) / 2\right]$. I do not require firms to be present in both eras. The regression controls for the standard set of lagged controls, defined over the same years as the earliest lagged capital.
} 


\section{Online Appendix D: Controlling for Contemporaneous Tax Changes (results reported in Online Appendix Table 6)}

The paper's identifying assumption is that C- and S-corporation outcomes would have trended similarly in the absence of the 2003 dividend tax cut. As mentioned in Section I.B, accelerated depreciation allowances and small changes to other tax rates were enacted 2001-2003, and these contemporaneous tax reforms could in principle have affected C- and S-corporations differently enough to confound the paper's quasi-experiment. Specifically, the Economic Growth and Tax Relief Reconciliation Act of 2001 ("EGTRRA") instituted a gradual reduction in the top federal individual ordinary income tax rate from $39.6 \%$ to $39.1 \%$ in $2001,38.6 \%$ in 2002 2003, 37.6\% in 2004-2005, and 35\% in 2006. The Job Creation and Worker Assistance Act of 2002 ("JCWAA") instituted accelerated depreciation for equipment and light structures investment, allowing firms to immediately deduct from their taxable income $30 \%$ of the purchase price of eligible investment placed into service between September 11, 2001 and September 11, 2004. The 2003 tax reform increased the accelerated depreciation allowance from $30 \%$ to $50 \%$ through December 31, 2004, accelerated from 2006 to 2003 the reduction in the top individual ordinary income tax rate to $35 \%$, and reduced the top individual capital gains tax rate from $20 \%$ to $15 \%$. The Economic Stimulus Act of 2008 reinstated for 2008 the temporary accelerated depreciation provisions of the 2003 tax reform. ${ }^{64}$

As detailed in Section III.E, the pre-2003 enactments of EGTRRA and JCWAA provide reduced-form "placebo" tests for quantitatively important effects of both accelerated depreciation and the change in the top ordinary income tax rate. The results of these tests suggest no important violations of the identifying assumption. This online appendix details additional tests that control for the effects of these contemporaneous tax changes on investment incentives, the results of which are reported in Online Appendix Table 6 columns 4-10. The controls barely change the results. Econometrically, the reason is that the contemporaneous tax changes either (in the cases of accelerated depreciation and the capital gains tax rate) had similar effects on investment incentives for C-corporations and S-corporations or (in the case of the ordinary income tax rate) affected S-corporation incentives relative C-corporation incentives similarly before and after 2003.

(D.i) Reduced-Form Controls for the Effects of Accelerated Depreciation

The temporary accelerated depreciation provisions of JCWAA and the 2003 tax reform have been found to have had quantitatively large effects on investment (House and Shapiro 2008; Zwick and Mahon 2014) - likely due to some combination of inducing substantial intertemporal substitution (House and Shapiro) or substantially relaxing financing constraints (Zwick and Mahon) in ways that the relatively small changes in the ordinary income tax rate and the capital gains tax rate likely did not. ${ }^{65}$ Hence, temporary accelerated depreciation could be a particularly quantitatively important confound. Below, I include structural controls for the

\footnotetext{
${ }^{64}$ EGTRRA was introduced into Congress in May 2001 and signed into law on June 7, 2001. JCWAA was introduced into Congress in October 2001 and signed into law on March 9, 2002. The Economic Stimulus Act of 2008 was introduced into Congress in January 2008 and signed into law on February 7, 2008.

${ }^{65}$ House and Shapiro argue that temporary accelerated depreciation induces especially large increases in investment because the intertemporal elasticity of investment approaches infinity for infinitely-lived capital goods. Zwick and Mahon argue that the observed effects of accelerated depreciation are inconsistent with intertemporal substitution alone but can be explained by a relaxation in financing constraints induced by accelerated depreciation.
} 
effects of accelerated depreciation on investment incentives, but I first include reduced-form controls for these effects, with results reported in Online Appendix Table 6 column 4.

Corporations deduct the nominal cost of each investment purchase from their annual taxable income in a series of annual deductions over an "asset life" (also known as a recovery period) that depends on the durability of the investment property. For example, cars are assigned an asset life of five years while warehouses are assigned an asset life of thirty-nine years. New purchases of investment property with asset lives of twenty years or less were eligible for accelerated depreciation, and within that eligible category, property with longer asset lives received greater subsidies because of discounting (see e.g. House and Shapiro 2008). Thus to control flexibly for the effects of temporary accelerated depreciation across firms with different asset life mixes, I control for a very flexible function of each firm's asset life mix interacted with year fixed effects. Specifically, I use the itemized investment fields of Form 4562 to construct two variables for each firm-year observation: ELIGIBLESHARE $E_{i t}$ equal to the share of firm $i$ 's investment over years $t-2$ and $t-1$ with an asset life of twenty years or less, and MEANELIGIBLELIF $E_{i t}$ equal to the mean asset life of firm $i$ 's investment over years $t-2$ and $t-1$ with asset life of twenty years or less. ${ }^{6}$ I then construct a quartic in ELIGIBLESHARE $E_{i t}$ and a quartic in $M E A N E L I G I B L E L I F E_{i t}$ and fully interact those quartics together and also with year fixed effects, yielding a new 208-variable $(=4 \times 4 \times 13)$ vector of controls to include in the main investment specification. These interactions flexibly absorb time-varying nonlinear effects of these two variables on investment.

Column 4 displays the estimated effect of the 2003 dividend tax on C-corporation investment after controlling for this flexible vector of asset life controls. The addition of this vector of controls barely changes the point estimate and confidence interval. The econometric reasons are straightforward. First, the main specification is reweighted on two-digit NAICS industry codes within each year, so cross-industry differences were already flexibly controlled for. Second and sufficient on its own, the distribution of asset lives of C-corporations and S-corporations in my sample are nearly identical: the C-corporation means of ELIGIBLESHARE $E_{i t}$ and $M E A N E L I G I B L E L I F E_{i t}$ are $85 \%$ and 6.05 years, while the S-corporation means are $84 \%$ and 6.04 years, respectively, implying that accelerated depreciation subsidized investment similarly for the two types of corporations.

(D.ii) Structural Controls for the Combined Effect of Contemporaneous Tax Changes

(a) Primary specification and inputs. Whereas column 4 flexibly controls for the effect of accelerated depreciation only, columns 5-10 use the investment model of Auerbach and Hassett (1992, hereafter "AH") to control for the combined effect of contemporaneous changes in the top individual ordinary income tax rate, the capital gains tax rate, and accelerated depreciation on firms' (user) cost of capital: the required pre-tax rate of return on marginal investments.

An extensive literature in the 1980s (e.g. Summers 1981; Abel 1982; Feldstein 1982; Auerbach and Hines 1987; Auerbach 1989) extended the canonical model of investment, taxes, and the cost of capital (Hall and Jorgenson 1967) to encompass microfounded adjustment costs and

\footnotetext{
${ }^{66}$ More precisely, eligible property comprises property depreciable under the General Depreciation System (GDS) of the Modified Accelerated Cost Recovery System with an asset life of 20 years or less. Property required to be depreciated under the Alternative Depreciation System (ADS, typically property installed outside the United States) was not eligible regardless of asset life, so the small fraction of investment depreciated under ADS is not included in ELIGIBLESHARE $E_{i t}$ or MEANELIGIBLELIFE $E_{i t}$. I assume that the small fraction of investment expensed under Section 179 was eligible.
} 
more features of the tax code. Linearizing from a firm's steady state and still ignoring certain features of the tax code such as dividend taxation and tax loss asymmetries, AH solved for a representative firm's optimal investment path as a direct function of tax rates (rather than an indirect function of the shadow price of capital " $q$ ") in discrete time, applied it to aggregate U.S. time series data, and reported estimates of adjustment costs and of cost-of-capital effects on investment that are useful in the present exercise. I now reprint AH's key investment equation for easy reference here, specify this paper's empirical implementation which closely follows AH and Cohen, Hansen, and Hassett (2002), and report the regression results.

$\mathrm{AH}$ consider a representative forward-looking value-maximizing U.S. firm that smooths its investment over time because of quadratic adjustment costs. $\mathrm{AH}$ derive the firm's optimal investment rule in which investment is high relative to lagged capital assets when the present year's or immediately upcoming years' costs of capital are low relative to its steady-state value and when the firm's capital stock is low relative to its steady-state value. Specifically, optimal investment approximately equals:

$$
\frac{I_{t}}{K_{t-1}}=\left[\left(\frac{1-\mu_{1}}{\alpha}\right)+n+\delta_{t}\right]-\left(\frac{1-\mu_{1}}{\alpha c_{K}^{*}}\right) E_{t} \sum_{s=t}^{\infty} w_{s-t} c_{s}\left(K_{t-1}\right)^{\alpha}
$$

where $I_{t}$ denotes investment in year $t, K_{t-1}$ denotes the lagged tangible capital stock, $\alpha$ is a measure of the curvature of the production function, $n$ is the trend growth-rate of total factor productivity, the terms $w_{s-t}$ are geometrically declining weights that sum to one and are a function of adjustment cost parameters, $\mu_{1}$ is a function of adjustment cost parameters, $\delta_{t}$ denotes the stochastic year- $t$ depreciation rate with $E\left(\delta_{t}\right)=\bar{\delta}, c_{K}^{*}$ denotes the steady-state value of the summation, and $c_{s}$ denotes a measure of the cost of capital for investment purchases made in year $s$ :

$$
c_{s}=\frac{\left(1-\Gamma_{s}\right)\left(\rho+\bar{\delta}+\frac{\Gamma_{s+1}-\Gamma_{s}}{1-\Gamma_{s}}\right) g}{\left(1-\tau_{s}^{b i z}\right) \theta_{s}}
$$

where $\tau_{s}^{b i z}$ denotes the business income tax rate in year $s, g$ denotes the relative price of capital goods, $\theta_{s}$ denotes stochastic productivity in year $s, \rho$ is the discount rate applied to the firm's risky cash flows, and $\Gamma_{s}$ denotes the present-value of tax savings from depreciation deductions $D_{z-s}$ per dollar of investment:

$$
\Gamma_{s}=\sum_{z=s}^{\infty}(1+r)^{-(z-s)} \tau_{z}^{b i z} D_{z-s}
$$

where $r$ equals the economy's risk-free rate of return. ${ }^{67} \mathrm{AH}$ focus on C-corporations, so $\tau_{s}^{b i z}$ in AH's empirical implementation refers to the corporate income tax rate. As in AH, let "cost of capital" $C O C_{t}$ refer to the summation term, which is a weighted average of current and future capital costs for a given steady state: $C O C_{t}=E_{t} \sum_{s=t}^{\infty} w_{s-t} c_{s}\left(K_{t-1}\right)^{\alpha}$. AH parameterize the future stream of costs of capital for each year $t$ in 1953-1988, estimate the best-fit rate of geometric decline in weights $w_{s-t}$ for aggregate equipment investment and separately for aggregate structures investment, and estimate equation (4) for equipment investment and separately for structures investment by regressing aggregate investment as a share of lagged capital on a constant and on the cost of capital.

\footnotetext{
${ }^{67}$ I omit the investment tax credit from equation (5) since that has long since been repealed.
} 
In Online Appendix Table 6, I repeat the paper's main specification on the main analysis sample while controlling additionally for the two potential firm-year-level omitted variables illuminated by equation (4): the cost of capital encompassing all taxes except for dividend taxes $\left(C O C_{i t}\right.$, which varies by firm-year according to the corporation type, tax regime, and firm's asset mix) and the depreciation rate $\left(\delta_{i t}\right.$, which varies by firm-year according to the firm's asset mix). I compute each firm-year's cost of capital $C O C_{i t}$ equal to the $\mathrm{AH}$ cost of capital $C O C_{t}$, averaged over the firm's asset mix and under the firm type's business income tax rate:

$$
C O C_{i t}=E_{t} \sum_{s=t}^{\infty} \sum_{a \in A} \lambda_{i t}^{a} w_{s-t}^{a} c_{c c o r p(i), s}^{a}\left(K_{i, t-1}\right)^{\alpha}
$$

where $\operatorname{ccorp}(i)$ denotes whether firm $i$ is a C-corporation and where $a$ denotes an asset life category within the full set of asset life categories $A .^{68}$ I follow Cohen, Hansen, and Hassett (2002, hereafter "CHH") in computing asset-life-specific costs of capital, which I then weight by each firm's asset life mix. Specifically, the cost of purchasing a dollar of asset type $a$ in year $s$ equals:

$$
c_{\operatorname{corp}(i), s}^{a}=\frac{\left(1-\Gamma_{c \operatorname{corp}(i), s}^{a}\right)\left(\rho_{c \operatorname{corp}(i), t}+\delta^{a}+\frac{\Gamma_{c \operatorname{corp}(i), s+1}^{a}-\Gamma_{c \operatorname{corp}(i), s}^{a}}{1-\Gamma_{\operatorname{ccorp}(i), s}^{a}}\right) g}{\left(1-\tau_{\operatorname{ccorp}(i), s}^{b i z}\right) \theta_{i s}}
$$

where $\tau_{c c o r p(i), s}^{b i z}$ equals the expected (at time $t$ ) corporate income tax rate in year $s$ if $i$ is a C-corporation and equals the expected top individual ordinary income tax rate in year $s$ if $i$ is an S-corporation, $\Gamma_{c c o r p(i), s}^{a}$ equals $\Gamma_{s}^{a}$ (equation 5) under the corresponding set of $\tau_{c c o r p}^{b i z), z}$ values and under the depreciation schedule for property of asset type $a, \delta^{a}$ equals the fixed economic depreciation rate of property in asset type $a$, and $\rho_{\text {ccorp }(i), t}$ (following CHH's extension of $\mathrm{AH}$ ) is a weighted average of required rates of return on debt and equity:

$$
\rho_{\text {ccorp }(i), t}=\bar{b}\left[\frac{(r+\pi)\left(1-\tau_{c c o r p(i), t}^{b i z}\right)}{1-\tau_{t}^{\text {ord }}}-\pi\right]+(1-\bar{b})\left[\frac{r^{e}+\pi \tau_{t}^{a c g}}{1-\tau_{t}^{a c g}}\right]
$$

where $\bar{b}$ is the average debt share of enterprise value, $\pi$ denotes the inflation rate, $\tau_{t}^{\text {ord }}$ denotes the top individual ordinary income tax rate, $r^{e}$ equals the rate of return on equity, and $\tau_{t}^{a c g}$ equals the tax rate on accrued capital gains. The weight $w_{s-t}^{a}$ refers to either an equipment weight or a structures weight, depending on asset type $a$. Asset life share $\lambda_{i t}^{a}$ equals the share of firm $i$ 's total investment across years $t-2$ and $t-1$ that was in asset category $a .{ }^{69}$

I follow $\mathrm{CHH}$ as closely as possible in parameterizing equation (6). ${ }^{70}$ Specifically, I follow CHH in assuming $\bar{b}=.4, r=.025, \pi=.03$, and $r^{e}=.1$ and computing $\tau_{\text {ccorp }(i), s}^{b i z}$ as equal to 1.3 times the statutory top business income tax rate (either corporate income tax rate or ordinary

\footnotetext{
${ }^{68}$ See Online Appendix D.i for a description of asset lives.

${ }^{69}$ In years with accelerated depreciation, I impute accelerated depreciation allowances pro-rata to eligible investment categories. Investment in these and other GDS investment categories constitute the vast majority of investment in my sample. Because five years is the modal GDS asset life, I assume that the small share of investment expensed under Section 179 or as listed property has an asset life of five years. Because ADS asset lives are typically a few years longer than the properties' corresponding GDS asset lives, I assume that the small share of investment in the ADS class life category has an asset life of nine years.

${ }^{70}$ I thank Kevin Hassett for kindly providing template code from $\mathrm{CHH}$.
} 
income tax rate) in order to account for inventory tax penalties. ${ }^{71}$ I further follow $\mathrm{CHH}$ by using depreciation schedules for each asset type $a$ assuming the half-year convention as reported in IRS Publication 946 and in assuming that the level-shifter $g\left(K_{i, t-1}\right)^{\alpha} / \theta_{i s}$ equals unity. ${ }^{72}$ I depart from $\mathrm{CHH}$ in areas necessary to conform to conventions used in the main text: I use state-plus-federal tax rates rather than just federal tax rates and (as in Desai and Goolsbee 2004) I assume that the tax rate on accrued capital gains equals one-quarter the statutory rate rather than the full statutory rate.

Finally and in addition to the firm-year-level asset life weights $\lambda_{i t}^{a}$ defined above, I extend $\mathrm{CHH}$ by constructing asset-life-specific depreciation rates, defining equipment investment and structures investment in terms of asset lives, and specifying a reasonable and minimally complicated path of tax rate expectations for this analysis. For each asset type $a$, I assign an economic depreciation rate $\delta^{a}$ equal to $47.3 \%$ of the best-fit non-accelerated-depreciation tax depreciation rate for that asset type. ${ }^{73}$ I compute the firm-year-level economic depreciation rates $\delta_{i t}$ equal to the average across economic depreciation rates $\delta^{a}$, weighted by the firm's asset-life weights:

$$
\delta_{i t}=\sum_{a \in A} \lambda_{i t}^{a} \delta^{a}
$$

I use AH's main equipment weight estimates (declining at rate .583) for asset lives of less than ten years and AH's main structures weight (declining at rate .95, indicating higher adjustment costs) for asset lives of ten years or more. ${ }^{74} \mathrm{I}$ follow $\mathrm{AH}$ in assuming that terminal tax rates (year-2008 in this sample) are expected to last forever whereas temporary accelerated depreciation is not. Except for terminal tax rates, I assume that tax reforms come as a surprise when legislated and are expected to be enacted as legislated. ${ }^{75}$

This paper's cost-of-capital measure is similar in both levels and in estimated investment effects to earlier work. This paper's overall mean level of the cost of capital is 0.24 , compared

\footnotetext{
${ }^{71}$ Reducing inflation and other rates to reflect the lower interest rate environment of the 2000s changes little, as does ignoring the inventory adjustment.

${ }^{72}$ This latter simplification is without loss of generality in the empirical analysis to the extent that productivity shocks are at the industry-year level and is shown below to have an evidently minor effect on both the levels and the observed investment effects of the cost of capital. This has the advantage of avoiding strong production function assumptions such as those adopted and rejected empirically by AH (p.154).

${ }^{73}$ House and Shapiro (2008, Appendix Table 2) assign economic geometric depreciation rates from Fraumeni (1997) to many types of investment. These economic depreciation rates are on average $47.3 \%$ of the corresponding best-fit geometric depreciation rate - reflecting the fact that economic depreciation is slower than tax depreciation in the United States even without accelerated depreciation (Auerbach 1989; House and Shapiro). In regressions of investment divided by lagged capital on the estimated economic depreciation rate of the firm's asset life mix $\delta_{i t}$, I obtain a very significant coefficient with magnitude close to one as would be expected near steady state, providing validation for these economic depreciation rates.

${ }^{74}$ That is, $w_{s-t}^{a}=(1 / .583-1)(1 / .583)^{-(s-t+1)}$ (see AH Table 2 column 1$)$ for asset types with lives less than ten years and $w_{s-t}^{a}=(1 / .95-1)(1 / .95)^{-(s-t+1)}$ for other asset types (see AH Table 3 column 1$)$. In the property classifications of Publication 946, light structures predominate beginning with asset lives of approximately 10 years (House and Shapiro).

${ }^{75}$ For example, the analysis makes the following assumptions. Firms before year 2001 expected pre-2001 tax rates to last forever. Firms in 2001 and 2002 expected the individual ordinary income tax rate to decline gradually through 2006 as legislated in 2001, were surprised when the 2003 tax reform accelerated that decline, and expected these declines to last forever. Firms were surprised when JCWAA introduced accelerated depreciation, when the 2003 tax reform expanded it, and when the Economic Stimulus Act of 2008 reinstated it. Firms in years 2002-2004 expected accelerated depreciation to be repealed beyond 2004 as legislated, and firms in year 2008 expected it to be repealed beyond 2008 as legislated.
} 
to AH's mean of 0.21 (reported on AH p.153). At the asset-type-year level, this paper's cost of capital measures are similar to CHH's (reported in CHH Table 2). Finally, the estimated effect of the cost of capital on investment as a share of lagged capital in this paper (i.e. the coefficient on the cost of capital in the regression underlying Online Appendix Table 6 column 7, detailed below) equals -0.457 , which is larger in magnitude and not significantly different from the average of AH's estimates of -0.253 for equipment investment and -0.045 for (quantitatively much less important) structures investment.

(b) Primary results. Online Appendix Table 6 column 7 repeats this paper's main investment specification on the main analysis sample with controls for the effects of contemporaneous nondividend-tax changes specified above: the cost of capital $C O C_{i t}$ and the depreciation rate $\delta_{i t}$. Relative to the paper's main results (reprinted in column 1), these controls have almost no effect on the point estimate and standard error. Column 8 controls for a quartic in the cost of capital rather than just linearly, with very similar results. Columns 5-6 show the same when controlling only for the depreciation rate or only for the cost of capital. ${ }^{76}$

Econometrically, the coefficient on the cost of capital in the regression underlying column 7 is substantial and negative (mentioned above), but the cost of capital is largely uncorrelated with the key interaction term (between the C-corporation indicator and the post-2003 indicator). Thus the omission of the cost of capital from the main specification induces little omitted variables bias. Economically, the cost of capital variable is conditionally uncorrelated with the interaction term because accelerated depreciation and the capital gains tax rate reduction had similar effects on the cost of capital for C- and S-corporations and because the reduction in the top individual ordinary income tax rate reduced S-corporations' cost of capital by similar magnitudes both before and after 2003. I explained in Online Appendix D.i why accelerated depreciation had similar effects across C- and S-corporations. The capital gains rate affects C- and S-corporations similarly via the discount rate $\rho_{\text {ccorp }(i), t}$. The legislated path of top ordinary income tax rate reductions immediately lowered S-corporations' cost of capital because economic depreciation is slower than tax depreciation, shown analytically in the very similar setup of Auerbach (1989 Section 3B).

(c) Extended cost-of-capital specification and results. This appendix's primary results implement a close analogue of AH's original empirical analysis in ignoring effects of contemporaneous tax changes on steady-state values of the cost of capital and the firm's capital stock when computing the cost of capital control $C O C_{i t}$. This omission need not be innocuous a priori: for example, temporarily low costs of capital under accelerated depreciation could in principle have induced firms to overshoot their target steady-state capital stocks by the end of 2004, implying unusually low investment in 2005 in spite of a lower value of $C O C_{i t}$ for $\mathrm{S}$-corporations relative to the pre-2003 period. Thus as an extra precaution though under strong assumptions, I extend AH's production function assumptions in order to account empirically for the expected path of capital stocks for C-corporations and S-corporations in an "extended" measure of the cost of capital EXTENDEDCOC it and control for this extended measure in the paper's main specification.

\footnotetext{
${ }^{76}$ When failing to control for the omitted variable $\delta_{i t}$, the coefficient on $C O C_{i t}$ is mechanically biased toward one, since firms specializing in long-lived capital obviously have lower investment rates (see equation 4). Controlling for $\delta_{i t}$ yields a negative coefficient on $C O C_{i t}$ as expected. $\mathrm{AH}$ control for economic depreciation rates by running separate regressions for each asset type (equipment and structures).
} 
AH's investment rule (equation 4) characterizes the law of motion of a representative firm's capital stock given adjustment costs, technology, and a path of tax rates: the firm increases its capital stock $K_{t-1}$ on net if and only if the current capital stock and the current and near-term capital costs are sufficiently low (i.e. if and only if $\left.E_{t} \sum_{s=t}^{\infty} w_{s-t} c_{s}\left(K_{t-1}\right)^{\alpha}<c_{t}^{*}\left(K_{t}^{*}\right)^{\alpha}\right)$ and to a degree that depends on the adjustment costs $\left(\mu_{1}\right)$ and the curvature of the production function $(\alpha)$. I therefore consider a representative $\mathrm{C}$-corporation and a representative $\mathrm{S}$-corporation (each with a corporation-type-specific asset life mix, averaged over the corporation type's observations 1998-2008) that was at its steady state in years 1998-2000, before the tax reforms considered here. Assuming $\alpha=.5$ (the midpoint of the feasible range) and solving for the $\mu_{1}$ consistent with $\alpha=.5$ and AH's cost of capital coefficients, I compute the estimated path of each representative corporation-type's capital stock $\hat{K}_{\text {ccorp }(i), t}$ and steady state capital stock $\hat{K}_{c c o r p(i), t}^{*} \cdot{ }^{77} \quad$ I then compute EXTENDEDCOC $i t$ as the main cost of capital $C O C_{i t}$, multiplied by a steady state factor indicating how much the current cost of capital and capital stock deviate from their steady-state values:

$$
\operatorname{EXTENDEDCOC} C_{i t}=\operatorname{COC}_{i t}\left(\frac{\left(\hat{K}_{\text {ccorp }(i), t-1}\right)^{\alpha}}{C O C_{i t}^{*}\left(\hat{K}_{\text {ccorp }(i), t}^{*}\right)^{\alpha}}\right)
$$

This equals one in steady state and is less than one when the firm's cost of capital is sufficiently low relative to its steady value or when the firm's capital stock is sufficiently low relative to its steady state value.

Online Appendix Table 6 columns 9-10 report results for the estimated effect of the dividend tax cut on investment when controlling for EXTENDEDCOC $C_{i t}$, instead of controlling for $C O C_{i t}$ as in columns 7-8. The results change very little. Econometrically, the reason is that $E X T E N D E D C O C_{i t}$ does not differ tremendously from $C O C_{i t}$. Economically, the reason is that AH's estimates (and a large but contentious literature) imply that adjustment costs are substantial, inducing substantial investment smoothing and thus no capital stock overshooting that could make $E X T E N D E D C O C_{i t}$ substantially different from $C O C_{i t}$ over time.

As a final discussion, note that the placebo test results from Section III.E (indicating that S-corporation investment did not rise significantly relative to C-corporation investment in years 2001-2002) may appear to conflict with the result from this cost-of-capital exercise that the cost of capital has a negative effect on investment and in which S-corporations' cost of capital fell relative to C-corporations' 2001-2002. In fact, the 95\% confidence interval lower bounds on the placebo tests are consistent with sizeable cost-of-capital effects on investment given the relatively small change in the cost of capital for S-corporations relative to C-corporations 20012002. Alternatively and due to frictions not present in standard models like AH, it is possible that investment responds more to accelerated depreciation (e.g. due to financial frictions as in Zwick and Mahon 2014) than to small changes in business income tax rates (e.g. due to optimization frictions as in Chetty 2012). By this alternative account, the zero result in the

\footnotetext{
${ }^{77} \mathrm{AH}$ report that the value of $\alpha$ implied by their empirical results exceeds the feasible range $[0,1]$ and statistically rejects the value (zero) implied by constant returns to scale. For AH's production function $F(K)=A K^{1-\alpha}$ and steady-state Euler equation $F^{\prime}\left(K_{t}^{*}\right)=\left[(\rho+\bar{\delta})\left(1-\Gamma_{t}^{*}\right) g /\left(1-\tau_{t}^{b i z^{*}}\right)\right]$ where $(\cdot)_{t}^{*}$ denotes an exepcted steady state value as of year $t$, the firm's steady state targeted capital stock grows between year $t-1$ and $t$ by factor $\left[\left(1-\tau_{t}^{b i z^{*}}\right) /\left(1-\tau_{t-1}^{b i z^{*}}\right)\right]^{1 / \alpha}\left[\left(1-\Gamma_{t-1}^{*}\right) /\left(1-\Gamma_{t}^{*}\right)\right]^{1 / \alpha}$. This year-on-year growth factor is all that is needed to compute the time path of each corporation type's capital stock in this exercise.
} 
placebo test is unsurprising given that the 2001-2002 cost-of-capital reduction for S-corporations was driven by the relatively small change in S-corporations' business income tax rate rather than by accelerated depreciation. Distinguishing between these explanations is left to future work. Regardless, none of the tests reported in Online Appendix 6 suggests that the paper's main estimate of the effect of the dividend tax cut on investment is confounded by effects of contemporaneous tax changes.

\section{References Used Only in the Online Appendix}

Abel, Andrew B. 1982. "Dynamic Effects of Permanent and Temporary Tax Policies in a $q$ Model of Investment." Journal of Monetary Economics, 9: 353-373.

Auerbach, Alan J. 1989. "Tax Reform and Adjustment Costs: The Impact of Investment on Market Value." International Economic Review, 30(4): 939-962.

Auerbach, Alan J., and James R. Hines. 1987. "Anticipated Tax Changes and the Timing of Investment." In The Effects of Taxation on Capital Accumulation, ed. Martin Feldstein, 163-200. Chicago: University of Chicago Press.

Feldstein, Martin. 1982. "Inflation, Tax Rules, and Investment: Some Econometric Evidence." In Inflation, Tax Rules, and Capital Formation, ed. Martin Feldstein, 243-286. Chicago: University of Chicago Press.

Salinger, Michael and Lawrence H. Summers. 1983. "Tax Reform and Corporate Investment: A Microeconometric Simulation Study." In Behavioral Simulation Methods in Tax Policy Analysis, ed. Martin Feldstein, 247-288. Chicago: University of Chicago Press.

Summers, Alan J. 1989. "Taxation and Corporate Investment: A q-Theory Approach." Brookings Papers on Economic Activity, 1981(1): 67-140. 
ONLINE APPENDIX TABLE 1

Effect of the 2003 Dividend Tax Cut on Investment, Net Investment, and Employee Compensation Allowing for Differential Pre-2003 Trends

\begin{tabular}{|c|c|c|c|c|c|c|}
\hline \multicolumn{7}{|l|}{ A. Investment } \\
\hline \multirow{5}{*}{$\begin{array}{r}\text { Dependent variable: } \\
\text { Dep. var. winsorized at: } \\
\text { Panel: }\end{array}$} & \multicolumn{6}{|c|}{ Investment } \\
\hline & \multicolumn{3}{|c|}{$95^{\text {th }}$ percentile } & \multicolumn{3}{|c|}{$99^{\text {th }}$ percentile } \\
\hline & \multicolumn{2}{|c|}{ Unbalanced } & \multirow{2}{*}{$\frac{\text { Balanced }}{(\$ \text { per } 96-97 \text { cap. })}$} & \multicolumn{2}{|c|}{ Unbalanced } & \multirow{3}{*}{$\begin{array}{c}\text { Balanced } \\
\text { (\$ per 96-97 cap.) } \\
(6) \\
\end{array}$} \\
\hline & \multicolumn{2}{|c|}{ (\$ per lagged capital) } & & \multicolumn{2}{|c|}{ (\$ per lagged capital) } & \\
\hline & (1) & $(2)$ & (3) & (4) & (5) & \\
\hline C-Corp $\times$ Post-2003 & $\begin{array}{l}-0.0123 \\
(0.0124)\end{array}$ & $\begin{array}{l}-0.0157 \\
(0.0119)\end{array}$ & $\begin{array}{l}-0.0600 \\
(0.0278)\end{array}$ & $\begin{array}{l}-0.0213 \\
(0.0196)\end{array}$ & $\begin{array}{l}-0.0255 \\
(0.0191)\end{array}$ & $\begin{array}{l}-0.2278 \\
(0.0810)\end{array}$ \\
\hline $\begin{array}{l}\text { Lagged controls } \\
\text { Firm FE's }\end{array}$ & & $x$ & $x$ & & $x$ & $x$ \\
\hline $\mathrm{N}$ (firm-years) & 333,029 & 333,029 & 85,624 & 333,029 & 333,029 & 85,624 \\
\hline Clusters (firms) & 73,188 & 73,188 & 7,784 & 73,188 & 73,188 & 7,784 \\
\hline $\mathrm{R}^{2}$ & 0.01 & 0.07 & 0.53 & 0.01 & 0.05 & 0.55 \\
\hline Pre-2003 C-corp mean & 0.2428 & 0.2428 & 0.2939 & 0.2828 & 0.2828 & 0.3682 \\
\hline Pre-2003 C-corp s.d. & 0.2514 & 0.2514 & 0.3070 & 0.4181 & 0.4181 & 0.6478 \\
\hline Implied $\varepsilon$ wrt $\left(1-\tau_{\text {div }}\right)$ & $\begin{array}{c}-0.12 \\
{[-0.35,0.11\rceil}\end{array}$ & $\begin{array}{c}-0.15 \\
{[-0.37,0.07\rceil}\end{array}$ & $\begin{array}{c}-0.47 \\
\lceil-0.9,-0.04\rceil\end{array}$ & $\begin{array}{c}-0.17 \\
\lceil-0.49,0.14\rceil\end{array}$ & $\begin{array}{c}-0.21 \\
{[-0.52,0.1]}\end{array}$ & $\begin{array}{c}-1.43 \\
{[-2.43,-0.43]}\end{array}$ \\
\hline \multicolumn{7}{|c|}{ B. Net Investment and Employee Compensation } \\
\hline \multirow{5}{*}{$\begin{array}{r}\text { Dependent variable: } \\
\text { Dep. var. winsorized at: } \\
\text { Panel: }\end{array}$} & \multicolumn{3}{|c|}{ Net Investment } & \multicolumn{3}{|c|}{ Employee compensation } \\
\hline & \multicolumn{3}{|c|}{$95^{\text {th }}$ percentile } & \multicolumn{3}{|c|}{$95^{\text {th }}$ percentile } \\
\hline & \multirow{2}{*}{\multicolumn{2}{|c|}{$\frac{\text { Unbalanced }}{\text { (\$ per lagged capital) }}$}} & Balanced & \multirow{2}{*}{\multicolumn{2}{|c|}{$\frac{\text { Unbalanced }}{\text { (\$ per lagged revenue) }}$}} & Balanced \\
\hline & & & (\$ per 96-97 cap.) & & & (\$ per 96-97 rev.) \\
\hline & $(7)$ & $(8)$ & $(9)$ & $(10)$ & $(11)$ & (12) \\
\hline C-Corp $\times$ Post-2003 & $\begin{array}{c}0.0246 \\
(0.0124)\end{array}$ & $\begin{array}{c}0.0217 \\
(0.0119)\end{array}$ & $\begin{array}{l}-0.0463 \\
(0.0348)\end{array}$ & $\begin{array}{c}0.0054 \\
(0.0057)\end{array}$ & $\begin{array}{c}0.0044 \\
(0.0047)\end{array}$ & $\begin{array}{c}0.0034 \\
(0.0061)\end{array}$ \\
\hline $\begin{array}{l}\text { Lagged controls } \\
\text { Firm FE's }\end{array}$ & & $\mathrm{x}$ & & & $x$ & \\
\hline Firm FE's & & & $\mathrm{X}$ & & & $\mathrm{X}$ \\
\hline $\mathrm{N}$ (firm-years) & 333,029 & 333,029 & 85,624 & 333,029 & 333,029 & 85,624 \\
\hline Clusters (firms) & 73,188 & 73,188 & 7,784 & 73,188 & 73,188 & 7,784 \\
\hline $\mathrm{R}^{2}$ & 0.01 & 0.04 & 0.20 & 0.00 & 0.37 & 0.88 \\
\hline Pre-2003 C-corp mean & 0.0421 & 0.0421 & 0.0885 & 0.1647 & 0.1647 & 0.1727 \\
\hline Pre-2003 C-corp s.d. & 0.2541 & 0.2541 & 0.2732 & 0.1415 & 0.1415 & 0.1450 \\
\hline Implied $\varepsilon$ wrt $\left(1-\tau_{\text {div }}\right)$ & $\begin{array}{c}1.35 \\
\lceil 0.01,2.69]\end{array}$ & $\begin{array}{c}1.20 \\
{[-0.09,2.48\rceil}\end{array}$ & $\begin{array}{c}-1.21 \\
{[-2.99,0.58]}\end{array}$ & $\begin{array}{c}0.08 \\
{[-0.08,0.23]}\end{array}$ & $\begin{array}{c}0.06 \\
\lceil-0.07,0.19]\end{array}$ & $\begin{array}{c}0.05 \\
{[-0.12,0.21]}\end{array}$ \\
\hline
\end{tabular}

Notes: This table replicates Table 2 except that it allows for differential pre-2003 trends by including an interaction between the post-2003 indicator and a year variable, as well as interacting the C-corporation indicator and the C-Corp $\times$ Post-2003 interaction with the year variable. The reported coefficient equals the estimated effect of the tax cut averaged over the post2003 period, equal to the coefficient on the C-Corp $\times$ Post-2003 interaction plus 2005.5 times the coefficient on the C-Corp $\times$ Post-2003 $\times$ year interaction, since 2005.5 is the mid-point of the post-2003 period. See the notes to Table 2 for additional details. 
ONLINE APPENDIX TABLE 2

Effect of the 2003 Dividend Tax Cut on Investment, Net Investment, and Employee Compensation Alternative Scalings

\begin{tabular}{|c|c|c|c|c|c|c|}
\hline \multicolumn{7}{|l|}{ A. Investment } \\
\hline \multirow{5}{*}{$\begin{array}{r}\text { Dependent variable: } \\
\text { Dep. var. winsorized at: } \\
\text { Panel: }\end{array}$} & \multicolumn{6}{|c|}{ Investment } \\
\hline & \multicolumn{3}{|c|}{$95^{\text {th }}$ percentile } & \multicolumn{3}{|c|}{$99^{\text {th }}$ percentile } \\
\hline & \multirow{2}{*}{\multicolumn{2}{|c|}{$\begin{array}{c}\text { Unbalanced } \\
\text { (\$ per lagged revenue) }\end{array}$}} & \multirow{3}{*}{$\begin{array}{c}\text { Balanced } \\
\text { (\$ per 96-97 rev.) } \\
(3) \\
\end{array}$} & \multirow{2}{*}{\multicolumn{2}{|c|}{$\begin{array}{c}\text { Unbalanced } \\
\text { (\$ per lagged revenue) }\end{array}$}} & \multirow{3}{*}{$\begin{array}{c}\text { Balanced } \\
\text { (\$ per 96-97 rev.) } \\
(6) \\
\end{array}$} \\
\hline & & & & & & \\
\hline & (1) & $(2)$ & & $(4)$ & (5) & \\
\hline C-Corp $\times$ Post-2003 & $\begin{array}{l}-0.0022 \\
(0.0005)\end{array}$ & $\begin{array}{l}-0.0021 \\
(0.0004)\end{array}$ & $\begin{array}{l}-0.0002 \\
(0.0012)\end{array}$ & $\begin{array}{l}-0.0036 \\
(0.0007)\end{array}$ & $\begin{array}{l}-0.0033 \\
(0.0007)\end{array}$ & $\begin{array}{l}-0.0005 \\
(0.0017)\end{array}$ \\
\hline $\begin{array}{l}\text { Lagged controls } \\
\text { Firm FE's }\end{array}$ & & $x$ & $\mathrm{X}$ & & $\mathrm{X}$ & $\mathrm{X}$ \\
\hline $\mathrm{N}$ (firm-years) & 333,029 & 333,029 & 85,624 & 333,029 & 333,029 & 85,624 \\
\hline Clusters (firms) & 73,188 & 73,188 & 7,784 & 73,188 & 73,188 & 7,784 \\
\hline $\mathrm{R}^{2}$ & 0.01 & 0.16 & 0.64 & 0.01 & 0.13 & 0.63 \\
\hline $\begin{array}{l}\text { Pre-2003 C-corp mean } \\
\text { Pre-2003 C-corp s.d. }\end{array}$ & $\begin{array}{l}0.0243 \\
0.0322\end{array}$ & $\begin{array}{l}0.0243 \\
0.0322\end{array}$ & $\begin{array}{l}0.0319 \\
0.0409\end{array}$ & $\begin{array}{l}0.0292 \\
0.0524\end{array}$ & $\begin{array}{l}0.0292 \\
0.0524\end{array}$ & $\begin{array}{l}0.0368 \\
0.0602\end{array}$ \\
\hline Implied $\varepsilon$ wrt $\left(1-\tau_{\text {div }}\right)$ & $\begin{array}{c}-0.21 \\
{[-0.3,-0.12]}\end{array}$ & $\begin{array}{c}-0.20 \\
{[-0.28,-0.12\rceil}\end{array}$ & $\begin{array}{c}-0.01 \\
{[-0.19,0.16]}\end{array}$ & $\begin{array}{c}-0.29 \\
\lceil-0.4,-0.17\rceil\end{array}$ & $\begin{array}{c}-0.26 \\
\lceil-0.37,-0.16\rceil\end{array}$ & $\begin{array}{c}-0.03 \\
{[-0.24,0.18]}\end{array}$ \\
\hline \multicolumn{7}{|c|}{ B. Net Investment and Employee Compensation } \\
\hline \multirow{5}{*}{$\begin{array}{r}\text { Dependent variable: } \\
\text { Dep. var. winsorized at: } \\
\text { Panel: }\end{array}$} & \multicolumn{3}{|c|}{ Net Investment } & \multicolumn{3}{|c|}{ Employee compensation } \\
\hline & \multicolumn{3}{|c|}{$95^{\text {th }}$ percentile } & \multicolumn{3}{|c|}{$95^{\text {th }}$ percentile } \\
\hline & \multirow{2}{*}{\multicolumn{2}{|c|}{$\frac{\text { Unbalanced }}{\text { (\$ per lagged revenue) }}$}} & Balanced & \multirow{2}{*}{\multicolumn{2}{|c|}{$\frac{\text { Unbalanced }}{\text { (\$ per lagged capital) }}$}} & Balanced \\
\hline & & & (\$ per 96-97 rev.) & & & (\$ per $96-97$ cap.) \\
\hline & (7) & (8) & (9) & (10) & $(11)$ & (12) \\
\hline C-Corp $\times$ Post-2003 & $\begin{array}{l}-0.0001 \\
(0.0003)\end{array}$ & $\begin{array}{l}-0.0001 \\
(0.0003)\end{array}$ & $\begin{array}{l}-0.0007 \\
(0.0012)\end{array}$ & $\begin{array}{l}-0.0103 \\
(0.1076)\end{array}$ & $\begin{array}{l}-0.0538 \\
(0.0949)\end{array}$ & $\begin{array}{c}0.1570 \\
(0.1564)\end{array}$ \\
\hline Lagged controls & & $x$ & & & $x$ & \\
\hline Firm FE's & & & $\mathrm{X}$ & & & $x$ \\
\hline $\mathrm{N}$ (firm-years) & 333,029 & 333,029 & 85,624 & 333,029 & 333,029 & 85,624 \\
\hline Clusters (firms) & 73,188 & 73,188 & 7,784 & 73,188 & 73,188 & 7,784 \\
\hline $\mathrm{R}^{2}$ & 0.01 & 0.05 & 0.23 & 0.02 & 0.18 & 0.90 \\
\hline Pre-2003 C-corp mean & 0.0025 & 0.0025 & 0.0074 & 3.1821 & 3.1821 & 2.8741 \\
\hline Pre-2003 C-corp s.d. & 0.0262 & 0.0262 & 0.0280 & 3.9833 & 3.9833 & 3.6007 \\
\hline Implied $\varepsilon$ wrt $\left(1-\tau_{\text {div }}\right)$ & $\begin{array}{c}-0.13 \\
{[-0.75,0.49]}\end{array}$ & $\begin{array}{c}-0.11 \\
{[-0.7,0.48]}\end{array}$ & $\begin{array}{c}-0.23 \\
{[-0.94,0.49]}\end{array}$ & $\begin{array}{c}-0.01 \\
{[-0.16,0.15]}\end{array}$ & $\begin{array}{c}-0.04 \\
{[-0.17,0.1]}\end{array}$ & $\begin{array}{c}0.13 \\
{[-0.12,0.37\rceil}\end{array}$ \\
\hline
\end{tabular}

Notes: This table replicates Table 2 except that outcomes that were scaled by lagged tangible capital are now scaled by lagged revenue, and vice versa. See the notes to that table for details. 
ONLINE APPENDIX TABLE 3

Effect of the 2003 Dividend Tax Cut on Investment, Net Investment, and Employee Compensation Years 1998-2004 Only

\begin{tabular}{|c|c|c|c|c|c|c|}
\hline \multicolumn{7}{|l|}{ A. Investment } \\
\hline \multirow{5}{*}{$\begin{array}{r}\text { Dependent variable: } \\
\text { Dep. var. winsorized at: } \\
\text { Panel: }\end{array}$} & \multicolumn{6}{|c|}{ Investment } \\
\hline & \multicolumn{3}{|c|}{$95^{\text {th }}$ percentile } & \multicolumn{3}{|c|}{$99^{\text {th }}$ percentile } \\
\hline & \multicolumn{2}{|c|}{ Unbalanced } & \multirow{2}{*}{$\frac{\text { Balanced }}{(\$ \text { per } 96-97 \text { cap. })}$} & \multicolumn{2}{|c|}{ Unbalanced } & \multirow{3}{*}{$\begin{array}{c}\text { Balanced } \\
\text { (\$ per 96-97 cap.) } \\
(6)\end{array}$} \\
\hline & \multicolumn{2}{|c|}{ (\$ per lagged capital) } & & \multicolumn{2}{|c|}{ (\$ per lagged capital) } & \\
\hline & (1) & $(2)$ & (3) & (4) & (5) & \\
\hline C-Corp $\times$ Post-2003 & $\begin{array}{l}-0.0145 \\
(0.0053)\end{array}$ & $\begin{array}{l}-0.0136 \\
(0.0051)\end{array}$ & $\begin{array}{l}-0.0256 \\
(0.0235)\end{array}$ & $\begin{array}{l}-0.0312 \\
(0.0085)\end{array}$ & $\begin{array}{l}-0.0299 \\
(0.0083)\end{array}$ & $\begin{array}{l}-0.1467 \\
(0.1204)\end{array}$ \\
\hline $\begin{array}{l}\text { Lagged controls } \\
\text { Firm FE's }\end{array}$ & & $x$ & $x$ & & $x$ & $x$ \\
\hline $\mathrm{N}$ (firm-years) & 232,787 & 232,787 & 54,488 & 232,787 & 232,787 & 54,488 \\
\hline Clusters (firms) & 63,048 & 63,048 & 7,784 & 63,048 & 63,048 & 7,784 \\
\hline $\mathrm{R}^{2}$ & 0.01 & 0.07 & 0.52 & 0.01 & 0.05 & 0.50 \\
\hline Pre-2003 C-corp mean & 0.2428 & 0.2428 & 0.2939 & 0.2828 & 0.2828 & 0.3682 \\
\hline Pre-2003 C-corp s.d. & 0.2514 & 0.2514 & 0.3070 & 0.4181 & 0.4181 & 0.6478 \\
\hline Implied $\varepsilon$ wrt $\left(1-\tau_{\text {div }}\right)$ & $\begin{array}{c}-0.14 \\
{[-0.24,-0.04\rceil}\end{array}$ & $\begin{array}{c}-0.13 \\
{[-0.22,-0.03]}\end{array}$ & $\begin{array}{c}-0.20 \\
{[-0.56,0.16]}\end{array}$ & $\begin{array}{c}-0.26 \\
{[-0.39,-0.12\rceil}\end{array}$ & $\begin{array}{c}-0.24 \\
{[-0.38,-0.11]}\end{array}$ & $\begin{array}{c}-0.92 \\
{[-2.4,0.56]}\end{array}$ \\
\hline \multicolumn{7}{|c|}{ B. Net Investment and Employee Compensation } \\
\hline \multirow{5}{*}{$\begin{array}{r}\text { Dependent variable: } \\
\text { Dep. var. winsorized at: } \\
\text { Panel: }\end{array}$} & \multicolumn{3}{|c|}{ Net Investment } & \multicolumn{3}{|c|}{ Employee compensation } \\
\hline & \multicolumn{3}{|c|}{$95^{\text {th }}$ percentile } & \multicolumn{3}{|c|}{$95^{\text {th }}$ percentile } \\
\hline & \multirow{2}{*}{\multicolumn{2}{|c|}{ Unbalanced }} & Balanced & \multirow{2}{*}{\multicolumn{2}{|c|}{ (\$ per lagged revenue) }} & Balanced \\
\hline & & & (\$ per 96-97 cap.) & & & (\$ per 96-97 rev.) \\
\hline & $(7)$ & $(8)$ & (9) & $(10)$ & $(11)$ & (12) \\
\hline C-Corp $\times$ Post-2003 & $\begin{array}{l}-0.0050 \\
(0.0052)\end{array}$ & $\begin{array}{l}-0.0040 \\
(0.0050)\end{array}$ & $\begin{array}{l}-0.0312 \\
(0.0146)\end{array}$ & $\begin{array}{l}-0.0040 \\
(0.0024)\end{array}$ & $\begin{array}{l}-0.0035 \\
(0.0020)\end{array}$ & $\begin{array}{c}0.0041 \\
(0.0052)\end{array}$ \\
\hline $\begin{array}{l}\text { Lagged controls } \\
\text { Firm FF's }\end{array}$ & & $\mathrm{x}$ & & & $x$ & \\
\hline Firm FE's & & & $\mathrm{X}$ & & & $\mathrm{X}$ \\
\hline $\mathrm{N}$ (firm-years) & 232,787 & 232,787 & 54,488 & 232,787 & 232,787 & 54,488 \\
\hline Clusters (firms) & 63,048 & 63,048 & 7,784 & 63,048 & 63,048 & 7,784 \\
\hline $\mathrm{R}^{2}$ & 0.02 & 0.05 & 0.23 & 0.00 & 0.37 & 0.91 \\
\hline Pre-2003 C-corp mean & 0.0421 & 0.0421 & 0.0885 & 0.1647 & 0.1647 & 0.1727 \\
\hline Pre-2003 C-corp s.d. & 0.2541 & 0.2541 & 0.2732 & 0.1415 & 0.1415 & 0.1450 \\
\hline Implied $\varepsilon$ wrt $\left(1-\tau_{\text {div }}\right)$ & $\begin{array}{c}-0.27 \\
\lceil-0.83,0.28\rceil\end{array}$ & $\begin{array}{c}-0.22 \\
\lceil-0.76,0.32\rceil\end{array}$ & $\begin{array}{c}-0.82 \\
{[-1.56,-0.07]}\end{array}$ & $\begin{array}{c}-0.06 \\
{[-0.12,0.01]}\end{array}$ & $\begin{array}{c}-0.05 \\
{[-0.1,0.01]}\end{array}$ & $\begin{array}{c}0.05 \\
{[-0.08,0.19]}\end{array}$ \\
\hline
\end{tabular}

Notes: This table replicates Table 2 except that it restricts the sample to years 1998-2004 only. See the notes to that table for details. 
ONLINE APPENDIX TABLE 4

Effect of the 2003 Dividend Tax Cut on Investment

Alternative Sample Frames, Variable Definitions, and Reweighting

\begin{tabular}{|c|c|c|c|c|c|c|c|c|c|c|}
\hline Variation: & $\begin{array}{l}\text { No variation } \\
\text { (reprinted from } \\
\text { Table } 2 \text { column } \\
\text { 2) } \\
\text { (1) }\end{array}$ & $\begin{array}{l}\text { Excluding } \\
\text { corporations } \\
\text { with foreign } \\
\text { operations } \\
\text { (2) }\end{array}$ & $\begin{array}{l}\text { Excluding } \\
\text { corporations } \\
\text { with high } \\
\text { officer } \\
\text { compensation } \\
\text { (3) }\end{array}$ & $\begin{array}{c}\text { Excluding } \\
\text { corporations } \\
\text { founded before } \\
1986 \\
(4)\end{array}$ & $\begin{array}{l}\text { No firm-size or } \\
\text { publicly traded } \\
\text { restriction } \\
\text { (5) }\end{array}$ & $\begin{array}{l}\text { Restricting to } \\
\text { dividend- } \\
\text { paying } \\
\text { corporations } \\
\text { (6) }\end{array}$ & $\begin{array}{l}\text { Restricting to } \\
\text { young } \\
\text { corporations } \\
\text { (7) }\end{array}$ & $\begin{array}{c}\text { Scaling } \\
\text { investment by } \\
\text { Salinger- } \\
\text { Summers } \\
\text { (1983) capital } \\
\text { stocks } \\
\text { (8) }\end{array}$ & $\begin{array}{l}\text { Propensity- } \\
\text { score matching } \\
\text { instead of DFL- } \\
\text { reweighting } \\
\text { (9) }\end{array}$ & $\begin{array}{c}\text { No reweighting } \\
(10)\end{array}$ \\
\hline C-Corp $\times$ Post-2003 & $\begin{array}{l}-0.0002 \\
(0.0042)\end{array}$ & $\begin{array}{l}-0.0005 \\
(0.0043)\end{array}$ & $\begin{array}{c}0.0015 \\
(0.0044)\end{array}$ & $\begin{array}{l}-0.0010 \\
(0.0110)\end{array}$ & $\begin{array}{l}-0.0247 \\
(0.0125)\end{array}$ & $\begin{array}{l}-0.0095 \\
(0.0059)\end{array}$ & $\begin{array}{l}-0.0251 \\
(0.0169)\end{array}$ & $\begin{array}{c}0.0010 \\
(0.0044)\end{array}$ & $\begin{array}{c}0.0032 \\
(0.0055)\end{array}$ & $\begin{array}{c}0.0019 \\
(0.0040)\end{array}$ \\
\hline $\mathrm{N}$ (firm-years) & 333,029 & 318,899 & 275,729 & 117,721 & 368,383 & 131,313 & 61,782 & 332,756 & 333,020 & 333,029 \\
\hline Clusters (firms) & 73,188 & 72,253 & 64,081 & 32,359 & 78,480 & 34,832 & 23,008 & 73,098 & 73,187 & 73,188 \\
\hline $\mathrm{R}^{2}$ & 0.07 & 0.07 & 0.06 & 0.08 & 0.10 & 0.07 & 0.09 & 0.06 & 0.06 & 0.06 \\
\hline Pre-2003 C-corp mean & 0.2428 & 0.2441 & 0.2385 & 0.2655 & 0.2158 & 0.2277 & 0.2805 & 0.2552 & 0.2395 & 0.2379 \\
\hline Pre-2003 C-corp s.d. & 0.2514 & 0.2562 & 0.2455 & 0.3097 & 0.1954 & 0.2133 & 0.3334 & 0.2655 & 0.2476 & 0.2430 \\
\hline Implied $\varepsilon$ wrt $\left(1-\tau_{\text {div }}\right)$ & $\begin{array}{c}0.00 \\
{[-0.08,0.08]}\end{array}$ & $\begin{array}{c}0.00 \\
{[-0.08,0.08]}\end{array}$ & $\begin{array}{c}0.01 \\
{[-0.07,0.1]}\end{array}$ & $\begin{array}{c}-0.01 \\
{[-0.2,0.18]}\end{array}$ & $\begin{array}{c}-0.27 \\
{[-0.53,0]}\end{array}$ & $\begin{array}{c}-0.10 \\
{[-0.21,0.02]}\end{array}$ & $\begin{array}{c}-0.21 \\
{[-0.48,0.07]}\end{array}$ & $\begin{array}{c}0.01 \\
{[-0.07,0.09]}\end{array}$ & $\begin{array}{c}0.03 \\
{[-0.07,0.13]}\end{array}$ & $\begin{array}{c}0.02 \\
{[-0.06,0.09]}\end{array}$ \\
\hline
\end{tabular}

Notes: This table reports results from repeating the paper's main investment regression specification (underlying Table 2 column 2 ) under alternative sample frames, variable definitions, and reweighting not already considered in Online Appendix Tables 1-3. For easy reference, column 1 reprints Table 2 column 2; see the notes to that table for specification details. The remaining columns replicate this main specification except for the variation specified in the column heading. Column 2 excludes corporations with an indication of foreign operations (defined as receiving a positive foreign tax credit in year $t-2$ ). Column 3 excludes corporations with high officer compensation (defined as having a top-quintile value of officer compensation divided by revenue in year $t-2$ ). Column 4 excludes corporations founded before the Tax Reform Act of 1986. Column 5 removes the paper's firm size upper bounds and privately held requirement and thus includes all publicly traded corporations that could be matched to the SOI data and survive the remaining sample restrictions. Column 6 restricts the sample to dividend-paying corporations (defined as those with a positive dividend in year $t-2$ ). Column 7 restricts the sample to young corporations (defined as those with bottom-quintile age). Column 8 scales investment by estimated capital stocks, computed using recursions on investment flows as in Salinger and Summers (1983); $0.1 \%$ of firms are excluded because estimated capital stocks could not be computed. Column 9 flexibly controls for differences between C- and S-corporations using propensity-score matching as in Dehejia and Wahba (2002) based on the full set of controls used in the main specification and the traits used in Table 3, rather than DFL-reweighting; nine observations are excluded from the regression because of insufficient overlap across treatment (C-corporations) and control (S-corporations) along within-year propensity score deciles. Column 10 implements no reweighting. See Online Appendix C.i for full detail. 
ONLINE APPENDIX TABLE 5

Effect of the 2003 Dividend Tax Cut on Investment

Scaling Investment by Pre-2003 Measures of Tangible Capital Assets

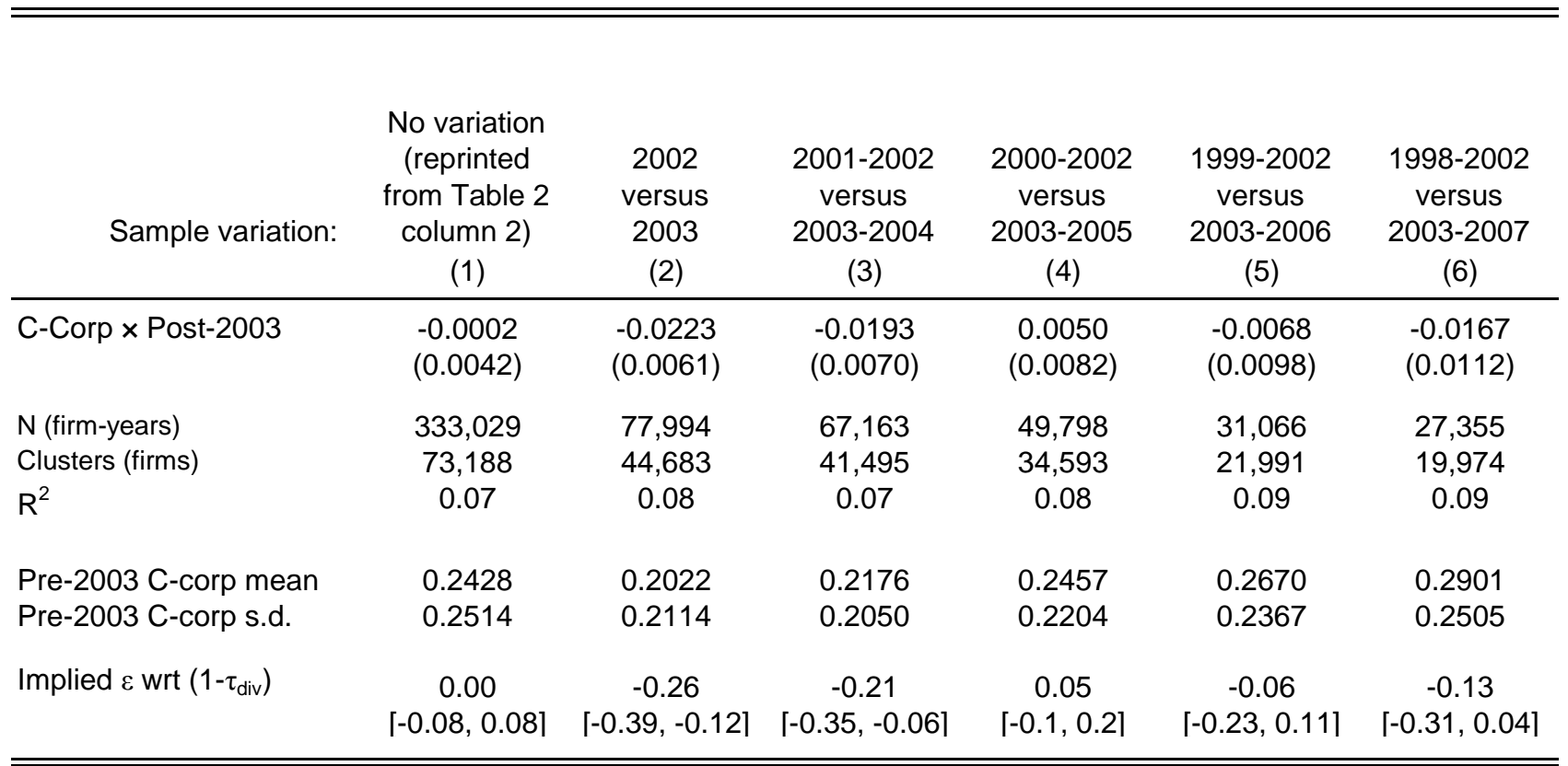

Notes: This table reports results from repeating the paper's main investment regression specification (underlying Table 2 column 2) when scaling investment by time-invariant pre-2003 measures of firm capital stocks. For easy reference, column 1 reprints Table 2 column 2; see the notes to that table for specification details. The remaining columns replicate this main specification except that they restrict to "firm-era" observations (i.e. either the pre-2003 era or the post-2003 era) on firms that are in my sample for a given number of years around 2003 (specified in the column heading) and compute investment as average annual investment divided by the earliest lagged tangible capital value available for that firm-era in the truncated time series. See Online Appendix C.ii for full detail. To convey the algorithm by example, consider the specification underlying column 4. I first restrict the pre-2003 subset of the main analysis sample to firms with observations in all years 2000-2002, and I restrict the post-2003 subset to firms with observations in all years 2003-2005. I then condense pre-2003 observations to one observation per firm with the dependent variable equal to $\left[\left(I_{i 2000}+I_{i 2001}+I_{i 2002}\right) / 3\right] /\left[\left(K_{i 1998}+K_{i 1999}\right) / 2\right]$ where $I_{i t}$ and $K_{i t}$ denote firm $i$ 's investment and tangible capital in year $t$, respetively, and condense post-2003 observations to one observation per firm with the dependent variable equal to $\left[\left(I_{2003}+I_{2004}+I_{2005}\right) / 3\right] /\left[\left(K_{2001}+K_{2002}\right) / 2\right]$. Because these specifications scale annual investment by pre-2003 measures of the firm's capital, any post-2003 increases in investment are not reflected in larger denominators in the scaled investment dependent variable. 
ONLINE APPENDIX TABLE 6

Effect of the 2003 Dividend Tax Cut on Investment

Placebo Tests and Controls for Contemporaneous Tax Changes

\begin{tabular}{|c|c|c|c|c|c|c|c|c|c|c|}
\hline & \multirow{2}{*}{$\begin{array}{c}\begin{array}{c}\text { None } \\
(\text { Table 2 } \\
\text { column 2) }\end{array} \\
\text { All } \\
(1)\end{array}$} & \multicolumn{2}{|c|}{ Pre-period placebos } & \multirow{2}{*}{$\begin{array}{c}\begin{array}{c}\text { Reduced- } \\
\text { form cost-of- } \\
\text { capital } \\
\text { controls }\end{array} \\
\text { All } \\
(4)\end{array}$} & \multicolumn{6}{|c|}{ Structural cost-of-capital controls } \\
\hline Sample years: & & $\begin{array}{c}1998-2001 \\
\text { (2) }\end{array}$ & $\begin{array}{c}1998-2000 \\
\text { and } 2002 \\
(3)\end{array}$ & & $\begin{array}{l}\text { All } \\
(5)\end{array}$ & $\begin{array}{l}\text { All } \\
(6)\end{array}$ & $\begin{array}{l}\text { All } \\
(7)\end{array}$ & $\begin{array}{l}\text { All } \\
(8)\end{array}$ & $\begin{array}{l}\text { All } \\
(9)\end{array}$ & $\begin{array}{l}\text { All } \\
(10)\end{array}$ \\
\hline C-Corp $\times$ Post-2003 & $\begin{array}{l}-0.0002 \\
(0.0042)\end{array}$ & & & $\begin{array}{l}-0.0021 \\
(0.0043)\end{array}$ & $\begin{array}{l}-0.0013 \\
(0.0043)\end{array}$ & $\begin{array}{l}-0.0018 \\
(0.0043)\end{array}$ & $\begin{array}{l}-0.0011 \\
(0.0043)\end{array}$ & $\begin{array}{l}-0.0012 \\
(0.0043)\end{array}$ & $\begin{array}{l}-0.0013 \\
(0.0043)\end{array}$ & $\begin{array}{l}-0.0019 \\
(0.0044)\end{array}$ \\
\hline C-Corp $\times$ Post-2001 & & $\begin{array}{c}0.0095 \\
(0.0067)\end{array}$ & $\begin{array}{c}0.0130 \\
(0.0071)\end{array}$ & & & & & & & \\
\hline \multicolumn{11}{|l|}{ Additional covariates: } \\
\hline Depreciation rate & & & & & $x$ & & $x$ & $x$ & $x$ & $x$ \\
\hline $\mathrm{AH}$ cost of capital (linear) & & & & & & $x$ & $x$ & & & \\
\hline AH cost of capital (quartic) & & & & & & & & $\mathrm{x}$ & & \\
\hline Extended AH cost of capital (linear) & & & & & & & & & $\mathrm{x}$ & \\
\hline Extended $\mathrm{AH}$ cost of capital (quartic) & & & & & & & & & & $\mathrm{x}$ \\
\hline $\mathrm{N}$ (firm-years) & 333,029 & 115,679 & 117,484 & 333,029 & 333,029 & 333,029 & 333,029 & 333,029 & 333,029 & 333,029 \\
\hline Clusters (firms) & 73,188 & 48,110 & 52,807 & 73,188 & 73,188 & 73,188 & 73,188 & 73,188 & 73,188 & 73,188 \\
\hline $\mathrm{R}^{2}$ & 0.07 & 0.06 & 0.07 & 0.09 & 0.08 & 0.08 & 0.08 & 0.08 & 0.08 & 0.08 \\
\hline Pre-2003 C-corp mean & 0.2428 & 0.2668 & 0.2668 & 0.2428 & 0.2428 & 0.2428 & 0.2428 & 0.2428 & 0.2428 & 0.2428 \\
\hline Pre-2003 C-corp s.d. & 0.2514 & 0.2627 & 0.2627 & 0.2514 & 0.2514 & 0.2514 & 0.2514 & 0.2514 & 0.2514 & 0.2514 \\
\hline Implied $\varepsilon$ wrt $\left(1-\tau_{\text {div }}\right)$ & $\begin{array}{c}0.00 \\
{[-0.08,0.08]}\end{array}$ & $\begin{array}{c}0.08 \\
{[-0.03,0.2]}\end{array}$ & $\begin{array}{c}0.11 \\
{[-0.01,0.23]}\end{array}$ & $\begin{array}{c}-0.02 \\
{[-0.1,0.06]}\end{array}$ & $\begin{array}{c}-0.01 \\
{[-0.09,0.07]}\end{array}$ & $\begin{array}{c}-0.02 \\
{[-0.1,0.06]}\end{array}$ & $\begin{array}{c}-0.01 \\
{[-0.09,0.07]}\end{array}$ & $\begin{array}{c}-0.01 \\
\lceil-0.09,0.07\rceil\end{array}$ & $\begin{array}{c}-0.01 \\
{[-0.09,0.07]}\end{array}$ & $\begin{array}{c}-0.02 \\
{[-0.1,0.06]}\end{array}$ \\
\hline
\end{tabular}

Notes: This table reports results from varying the paper's main investment regression specification (underlying Table 2 column 2) in order to conduct placebo tests or to control for effects of contemporaneous tax changes on firms' user cost of capital. For easy reference, column 1 reprints Table 2 column 2; see the notes to that table for specification details. The

remaining columns replicate this main specification except for the variation specified in the column heading and control rows. Columns 2-3 restrict the sample to the years specified in the column heading and replace the post-2003 indicator with a post-2001 indicator equal to 1 if the observation is from year 2001 or beyond. Column 4 includes controls for full interactions between a quartic in the share of the firm's lagged investment (summed over the previous two lags) made in accelerated-depreciation-eligible property (i.e. property with asset lives that were eligible for accelerated depreciation 2001-2004 and in 2008), a quartic in the mean asset life of the firm's lagged bonus-eligible investment, and year fixed effects. Column 5 includes controls for the mean depreciation rate of the firm's lagged investment, computed based on the firm's lagged investment asset life mix and the economic depreciation rates by asset life reported in House and Shapiro (2008). Columns 6-8 include controls for the firm-year's user cost of capital as a function of accelerated depreciation, the top corporate income tax rate, the top individual ordinary income tax rate, and the top individual capital gains tax rate as derived in Auerbach and Hassett (1992) and following closely the empirical implementations of Auerbach and Hassett and of Cohen, Hansen, and Hassett (2002). Columns 9-10 repeat columns 7-8 using a fuller and more structural cost-of-capital measure based on Auerbach and Hassett that accounts for tax-induced changes in firms' steady-state costs-of-capital and capital stocks. See Online Appendix D for full detail. 
ONLINE APPENDIX TABLE 7

Effect of the 2003 Dividend Tax Cut on Investment, Net Investment, and Employee Compensation Including Publicly Traded Corporations

\begin{tabular}{|c|c|c|c|c|c|c|}
\hline \multicolumn{7}{|l|}{ A. Investment } \\
\hline \multirow{5}{*}{$\begin{array}{r}\text { Dependent variable: } \\
\text { Dep. var. winsorized at: } \\
\text { Panel: }\end{array}$} & \multicolumn{6}{|c|}{ Investment } \\
\hline & \multicolumn{3}{|c|}{$95^{\text {th }}$ percentile } & \multicolumn{3}{|c|}{$99^{\text {th }}$ percentile } \\
\hline & \multicolumn{2}{|c|}{ Unbalanced } & Balanced & \multicolumn{2}{|c|}{ Unbalanced } & Balanced \\
\hline & \multicolumn{2}{|c|}{ (\$ per lagged capital) } & \multirow{2}{*}{$\begin{array}{c}\text { (\$ per 96-97 cap.) } \\
(3)\end{array}$} & \multicolumn{2}{|c|}{ (\$ per lagged capital) } & (\$ per 96-97 cap.) \\
\hline & (1) & $(2)$ & & (4) & $(5)$ & (6) \\
\hline C-Corp $\times$ Post-2003 & $\begin{array}{l}-0.0023 \\
(0.0052)\end{array}$ & $\begin{array}{l}-0.0019 \\
(0.0050)\end{array}$ & $\begin{array}{l}-0.0768 \\
(0.0598)\end{array}$ & $\begin{array}{l}-0.0081 \\
(0.0076)\end{array}$ & $\begin{array}{l}-0.0072 \\
(0.0073)\end{array}$ & $\begin{array}{l}-0.3312 \\
(0.2953)\end{array}$ \\
\hline $\begin{array}{l}\text { Lagged controls } \\
\text { Firm FE's }\end{array}$ & \multicolumn{3}{|c|}{$x$} & \multicolumn{3}{|c|}{$x$} \\
\hline $\mathrm{N}$ (firm-years) & 356,758 & 356,758 & 93,621 & 356,758 & 356,758 & 93,621 \\
\hline Clusters (firms) & 77,323 & 77,323 & 8,511 & 77,323 & 77,323 & 8,511 \\
\hline $\mathrm{R}^{2}$ & 0.01 & 0.08 & 0.55 & 0.01 & 0.06 & 0.60 \\
\hline Pre-2003 C-corp mean & 0.2479 & 0.2479 & 0.3033 & 0.2835 & 0.2835 & 0.3671 \\
\hline Pre-2003 C-corp s.d. & 0.2532 & 0.2532 & 0.3227 & 0.3962 & 0.3962 & 0.6031 \\
\hline Implied $\varepsilon$ wrt $\left(1-\tau_{\text {div }}\right)$ & $\begin{array}{c}-0.02 \\
{[-0.12,0.07\rceil}\end{array}$ & $\begin{array}{c}-0.02 \\
{[-0.11,0.07\rceil}\end{array}$ & $\begin{array}{c}-0.59 \\
{[-1.48,0.31]}\end{array}$ & $\begin{array}{c}-0.07 \\
{[-0.19,0.06]}\end{array}$ & $\begin{array}{c}-0.06 \\
{[-0.18,0.06]}\end{array}$ & $\begin{array}{c}-2.09 \\
{[-5.73,1.56]}\end{array}$ \\
\hline \multicolumn{7}{|c|}{ B. Net Investment and Employee Compensation } \\
\hline \multirow{5}{*}{$\begin{array}{r}\text { Dependent variable: } \\
\text { Dep. var. winsorized at: } \\
\text { Panel: }\end{array}$} & \multicolumn{3}{|c|}{ Net Investment } & \multicolumn{3}{|c|}{ Employee compensation } \\
\hline & \multicolumn{3}{|c|}{$95^{\text {th }}$ percentile } & \multicolumn{3}{|c|}{$95^{\text {th }}$ percentile } \\
\hline & & & Balanced & \multirow{2}{*}{\multicolumn{2}{|c|}{ (\$ per lagged revenue) }} & Balanced \\
\hline & \multicolumn{2}{|c|}{ (\$ per lagged capital) } & (\$ per 96-97 cap.) & & & (\$ per 96-97 rev.) \\
\hline & $(7)$ & $(8)$ & $(9)$ & $(10)$ & $(11)$ & $(12)$ \\
\hline C-Corp $\times$ Post-2003 & $\begin{array}{c}0.0005 \\
(0.0048)\end{array}$ & $\begin{array}{c}0.0011 \\
(0.0046)\end{array}$ & $\begin{array}{l}-0.0277 \\
(0.0119)\end{array}$ & $\begin{array}{l}-0.0013 \\
(0.0033)\end{array}$ & $\begin{array}{l}-0.0013 \\
(0.0026)\end{array}$ & $\begin{array}{c}0.0255 \\
(0.0091)\end{array}$ \\
\hline Lagged controls & \multicolumn{3}{|c|}{$x$} & \multicolumn{3}{|c|}{$\mathrm{X}$} \\
\hline Firm FE's & & & $\mathrm{X}$ & & & $\mathrm{X}$ \\
\hline $\mathrm{N}$ (firm-years) & 356,758 & 356,758 & 93,621 & 356,758 & 356,758 & 93,621 \\
\hline Clusters (firms) & 77,323 & 77,323 & 8,511 & 77,323 & 77,323 & 8,511 \\
\hline $\mathrm{R}^{2}$ & 0.02 & 0.06 & 0.22 & 0.01 & 0.38 & 0.86 \\
\hline Pre-2003 C-corp mean & 0.0484 & 0.0484 & 0.0984 & 0.1883 & 0.1883 & 0.2050 \\
\hline Pre-2003 C-corp s.d. & 0.2671 & 0.2671 & 0.2940 & 0.1551 & 0.1551 & 0.1689 \\
\hline Implied $\varepsilon$ wrt $\left(1-\tau_{\text {div }}\right)$ & $\begin{array}{c}0.02 \\
{[-0.42,0.47]}\end{array}$ & $\begin{array}{c}0.05 \\
{[-0.38,0.48]}\end{array}$ & $\begin{array}{c}-0.65 \\
{[-1.2,-0.1]}\end{array}$ & $\begin{array}{c}-0.02 \\
{[-0.1,0.06]}\end{array}$ & $\begin{array}{c}-0.02 \\
{[-0.08,0.05]}\end{array}$ & $\begin{array}{c}0.29 \\
\lceil 0.09,0.49\rceil\end{array}$ \\
\hline
\end{tabular}

Notes: This table replicates Table 2 except that it includes all publicly traded corporations that satisfy the sample restrictions (other than being privately held) listed in the notes to Table 1. See the notes to those tables for details. Publicly traded corporations were omitted from the main sample because all public corporations are C-corporations and thus may have no reasonable S-corporation counterparts. 
ONLINE APPENDIX TABLE 8

Effect of the 2003 Dividend Tax Cut on Total Payouts to Shareholders (Full Results)

\begin{tabular}{|c|c|c|c|c|c|c|}
\hline \multirow[t]{3}{*}{ Panel: } & \multicolumn{2}{|c|}{ Unbalanced } & \multirow{3}{*}{$\begin{array}{c}\text { Balanced } \\
(\%) \\
(3)\end{array}$} & \multicolumn{2}{|c|}{ Unbalanced } & \multirow{3}{*}{$\begin{array}{c}\text { Balanced } \\
(\%) \\
(6)\end{array}$} \\
\hline & $(\%)$ & $(\%)$ & & $(\%)$ & $(\%)$ & \\
\hline & (1) & $(2)$ & & (4) & (5) & \\
\hline \multicolumn{7}{|c|}{ A. Overall Difference-in-Differences Estimates } \\
\hline C-Corp $\times$ Post-2003 & $\begin{array}{l}23.4 \\
(3.6)\end{array}$ & $\begin{array}{l}27.6 \\
(3.3)\end{array}$ & $\begin{array}{l}78.1 \\
(8.0)\end{array}$ & $\begin{array}{l}39.4 \\
(7.3)\end{array}$ & $\begin{array}{l}45.5 \\
(6.5)\end{array}$ & $\begin{array}{c}53.6 \\
(15.1)\end{array}$ \\
\hline Lagged controls & & $x$ & & & $x$ & \\
\hline Firm FE's & & & $X$ & & & $\mathrm{X}$ \\
\hline Pre-trend controls & & & & $\mathrm{X}$ & $\mathrm{X}$ & $X$ \\
\hline N (firm-years) & 333,029 & 333,029 & 85,624 & 333,029 & 333,029 & 85,624 \\
\hline Clusters (firms) & 73,188 & 73,188 & 7,784 & 73,188 & 73,188 & 7,784 \\
\hline $\mathrm{R}^{2}$ & 0.01 & 0.13 & 0.54 & 0.01 & 0.13 & 0.54 \\
\hline $\begin{array}{l}\text { Pre-2003 C-corp mean } \\
\text { (\$ per lagged revenue) }\end{array}$ & 0.0031 & 0.0031 & 0.0061 & 0.0031 & 0.0031 & 0.0061 \\
\hline Implied $\varepsilon$ wrt $\left(1-\tau_{\text {div }}\right)$ & $\begin{array}{c}0.54 \\
{[0.38,0.7]}\end{array}$ & $\begin{array}{c}0.64 \\
{[0.49,0.79]}\end{array}$ & $\begin{array}{c}1.81 \\
{[1.44,2.17]}\end{array}$ & $\begin{array}{c}0.91 \\
{[0.58,1.24]}\end{array}$ & $\begin{array}{c}1.05 \\
{[0.76,1.35]}\end{array}$ & $\begin{array}{c}1.24 \\
{[0.55,1.92]}\end{array}$ \\
\hline \multicolumn{7}{|c|}{ B. Year-by-Year Difference-in-Differences Estimates } \\
\hline C-Corp $\times$ Year-2003 & $\begin{array}{l}18.1 \\
(4.3)\end{array}$ & $\begin{array}{l}21.4 \\
(4.1)\end{array}$ & $\begin{array}{l}58.5 \\
(8.8)\end{array}$ & $\begin{array}{l}26.2 \\
(4.8)\end{array}$ & $\begin{array}{l}30.5 \\
(4.6)\end{array}$ & $\begin{array}{c}45.1 \\
(11.3)\end{array}$ \\
\hline C-Corp $\times$ Year-2004 & $\begin{array}{l}32.1 \\
(5.2)\end{array}$ & $\begin{array}{l}35.6 \\
(5.0)\end{array}$ & $\begin{array}{c}66.6 \\
(11.4)\end{array}$ & $\begin{array}{l}43.3 \\
(6.5)\end{array}$ & $\begin{array}{l}48.3 \\
(6.2)\end{array}$ & $\begin{array}{c}48.8 \\
(10.4)\end{array}$ \\
\hline C-Corp $\times$ Year-2005 & $\begin{array}{l}26.8 \\
(5.8)\end{array}$ & $\begin{array}{l}29.8 \\
(5.5)\end{array}$ & $\begin{array}{c}81.4 \\
(12.4)\end{array}$ & $\begin{array}{l}41.2 \\
(8.2)\end{array}$ & $\begin{array}{l}46.0 \\
(7.5)\end{array}$ & $\begin{array}{c}59.1 \\
(16.6)\end{array}$ \\
\hline C-Corp $\times$ Year-2006 & $\begin{array}{l}16.5 \\
(5.8)\end{array}$ & $\begin{array}{l}21.5 \\
(5.5)\end{array}$ & $\begin{array}{c}78.5 \\
(13.1)\end{array}$ & $\begin{array}{l}34.0 \\
(9.3)\end{array}$ & $\begin{array}{l}41.2 \\
(8.4)\end{array}$ & $\begin{array}{l}51.8 \\
(20.7)\end{array}$ \\
\hline C-Corp × Year-2007 & $\begin{array}{l}15.4 \\
(5.7)\end{array}$ & $\begin{array}{l}21.3 \\
(5.4)\end{array}$ & $\begin{array}{c}78.1 \\
(12.7)\end{array}$ & $\begin{array}{c}36.0 \\
(10.3)\end{array}$ & $\begin{array}{l}44.4 \\
(9.2)\end{array}$ & $\begin{array}{c}46.9 \\
(23.0)\end{array}$ \\
\hline C-Corp $\times$ Year-2008 & $\begin{array}{l}30.1 \\
(6.2)\end{array}$ & $\begin{array}{l}34.6 \\
(5.8)\end{array}$ & $\begin{array}{l}105.3 \\
(13.9)\end{array}$ & $\begin{array}{c}53.9 \\
(11.7)\end{array}$ & $\begin{array}{c}61.3 \\
(10.4)\end{array}$ & $\begin{array}{c}69.7 \\
(24.1)\end{array}$ \\
\hline $\begin{array}{l}\text { Lagged controls } \\
\text { Firm FE's }\end{array}$ & & $\mathrm{X}$ & $X$ & & $\mathrm{X}$ & $X$ \\
\hline N (firm-years) & 333,029 & 333,029 & 85,624 & 333,029 & 333,029 & 85,624 \\
\hline Clusters (firms) & 73,188 & 73,188 & 7,784 & 73,188 & 73,188 & 7,784 \\
\hline $\mathrm{R}^{2}$ & 0.01 & 0.13 & 0.54 & 0.01 & 0.13 & 0.54 \\
\hline Implied $2003 \varepsilon$ wrt $\left(1-\tau_{\text {div }}\right)$ & $\begin{array}{c}0.42 \\
{[0.22,0.61]}\end{array}$ & $\begin{array}{c}0.49 \\
{[0.31,0.68]}\end{array}$ & $\begin{array}{c}1.35 \\
{[0.95,1.75]}\end{array}$ & $\begin{array}{c}0.61 \\
{[0.39,0.83]}\end{array}$ & $\begin{array}{c}0.71 \\
{[0.49,0.92]}\end{array}$ & $\begin{array}{c}1.04 \\
{[0.53,1.56]}\end{array}$ \\
\hline
\end{tabular}

Notes - This table reports full results from the regressions underlying Table 4. See the notes to that table for details. 
ONLINE APPENDIX TABLE 9

Effect of the 2003 Dividend Tax Cut on Dividend Payouts to Shareholders

\begin{tabular}{|c|c|c|c|c|c|c|}
\hline \multirow[t]{3}{*}{ Panel: } & \multicolumn{2}{|c|}{ Unbalanced } & \multirow{3}{*}{$\begin{array}{c}\text { Balanced } \\
(\%) \\
(3)\end{array}$} & \multicolumn{2}{|c|}{ Unbalanced } & \multirow{3}{*}{$\begin{array}{c}\text { Balanced } \\
(\%) \\
(6)\end{array}$} \\
\hline & $(\%)$ & $(\%)$ & & $(\%)$ & $(\%)$ & \\
\hline & $(1)$ & $(2)$ & & $(4)$ & $(5)$ & \\
\hline \multicolumn{7}{|c|}{ A. Overall Difference-in-Differences Estimates } \\
\hline C-Corp $\times$ Post-2003 & $\begin{array}{l}28.5 \\
(3.9)\end{array}$ & $\begin{array}{l}32.7 \\
(3.6)\end{array}$ & $\begin{array}{l}76.2 \\
(7.8)\end{array}$ & $\begin{array}{l}45.5 \\
(7.7)\end{array}$ & $\begin{array}{l}52.0 \\
(6.9)\end{array}$ & $\begin{array}{c}51.7 \\
(15.2)\end{array}$ \\
\hline Lagged controls & & $\mathrm{X}$ & & & $\mathrm{X}$ & \\
\hline Firm FE's & & & $\mathrm{X}$ & & & $\mathrm{X}$ \\
\hline Pre-trend controls & & & & $\mathrm{X}$ & $\mathrm{X}$ & $\mathrm{X}$ \\
\hline $\mathrm{N}$ (firm-years) & 333,029 & 333,029 & 85,624 & 333,029 & 333,029 & 85,624 \\
\hline Clusters (firms) & 73,188 & 73,188 & 7,784 & 73,188 & 73,188 & 7,784 \\
\hline $\mathrm{R}^{2}$ & 0.01 & 0.13 & 0.57 & 0.01 & 0.13 & 0.57 \\
\hline $\begin{array}{l}\text { Pre-2003 C-corp mean } \\
\text { (\$ per lagged revenue) }\end{array}$ & 0.0022 & 0.0022 & 0.0048 & 0.0022 & 0.0022 & 0.0048 \\
\hline Implied $\varepsilon$ wrt $\left(1-\tau_{\text {div }}\right)$ & $\begin{array}{c}0.66 \\
{[0.48,0.83]}\end{array}$ & $\begin{array}{c}0.76 \\
{[0.59,0.92]}\end{array}$ & $\begin{array}{c}1.76 \\
{[1.41,2.12]}\end{array}$ & $\begin{array}{c}1.05 \\
{[0.7,1.4]}\end{array}$ & $\begin{array}{c}1.20 \\
{[0.89,1.52]}\end{array}$ & $\begin{array}{c}1.20 \\
{[0.51,1.89]}\end{array}$ \\
\hline \multicolumn{7}{|c|}{ B. Year-by-Year Difference-in-Differences Estimates } \\
\hline C-Corp $\times$ Year-2003 & $\begin{array}{l}20.0 \\
(4.4)\end{array}$ & $\begin{array}{l}23.3 \\
(4.3)\end{array}$ & $\begin{array}{l}63.2 \\
(9.2)\end{array}$ & $\begin{array}{l}28.6 \\
(5.0)\end{array}$ & $\begin{array}{l}33.0 \\
(4.8)\end{array}$ & $\begin{array}{c}49.9 \\
(11.4)\end{array}$ \\
\hline C-Corp $\times$ Year-2004 & $\begin{array}{l}35.3 \\
(5.4)\end{array}$ & $\begin{array}{l}38.9 \\
(5.2)\end{array}$ & $\begin{array}{c}66.4 \\
(11.3)\end{array}$ & $\begin{array}{l}47.2 \\
(6.8)\end{array}$ & $\begin{array}{l}52.4 \\
(6.5)\end{array}$ & $\begin{array}{c}48.5 \\
(10.6)\end{array}$ \\
\hline C-Corp $\times$ Year-2005 & $\begin{array}{l}31.5 \\
(6.1)\end{array}$ & $\begin{array}{l}34.5 \\
(5.8)\end{array}$ & $\begin{array}{c}70.6 \\
(11.5)\end{array}$ & $\begin{array}{l}46.8 \\
(8.6)\end{array}$ & $\begin{array}{l}51.7 \\
(8.0)\end{array}$ & $\begin{array}{c}48.3 \\
(16.3)\end{array}$ \\
\hline C-Corp $\times$ Year-2006 & $\begin{array}{l}26.3 \\
(6.3)\end{array}$ & $\begin{array}{l}31.5 \\
(6.0)\end{array}$ & $\begin{array}{c}77.3 \\
(12.4)\end{array}$ & $\begin{array}{l}44.8 \\
(9.9)\end{array}$ & $\begin{array}{l}52.4 \\
(9.1)\end{array}$ & $\begin{array}{c}50.5 \\
(20.2)\end{array}$ \\
\hline C-Corp $\times$ Year-2007 & $\begin{array}{l}22.3 \\
(6.1)\end{array}$ & $\begin{array}{l}28.4 \\
(5.8)\end{array}$ & $\begin{array}{c}78.3 \\
(12.4)\end{array}$ & $\begin{array}{c}44.1 \\
(10.9)\end{array}$ & $\begin{array}{l}53.0 \\
(9.8)\end{array}$ & $\begin{array}{c}47.1 \\
(23.0)\end{array}$ \\
\hline C-Corp $\times$ Year-2008 & $\begin{array}{l}35.5 \\
(6.7)\end{array}$ & $\begin{array}{l}40.3 \\
(6.3)\end{array}$ & $\begin{array}{l}101.6 \\
(14.0)\end{array}$ & $\begin{array}{c}60.7 \\
(12.4)\end{array}$ & $\begin{array}{c}68.7 \\
(11.1)\end{array}$ & $\begin{array}{c}65.9 \\
(24.5)\end{array}$ \\
\hline $\begin{array}{l}\text { Lagged controls } \\
\text { Firm FE's }\end{array}$ & & $x$ & $\mathrm{X}$ & & $x$ & $\mathrm{X}$ \\
\hline N (firm-years) & 333,029 & 333,029 & 85,624 & 333,029 & 333,029 & 85,624 \\
\hline Clusters (firms) & 73,188 & 73,188 & 7,784 & 73,188 & 73,188 & 7,784 \\
\hline $\mathrm{R}^{2}$ & 0.01 & 0.13 & 0.57 & 0.01 & 0.13 & 0.57 \\
\hline Implied $2003 \varepsilon$ wrt $\left(1-\tau_{\text {div }}\right)$ & $\begin{array}{c}0.46 \\
{[0.26,0.66]}\end{array}$ & $\begin{array}{c}0.54 \\
{[0.35,0.73]}\end{array}$ & $\begin{array}{c}1.46 \\
{[1.05,1.88]}\end{array}$ & $\begin{array}{c}0.66 \\
{[0.44,0.89]}\end{array}$ & $\begin{array}{c}0.76 \\
{[0.55,0.98]}\end{array}$ & $\begin{array}{c}1.15 \\
{[0.64,1.67]}\end{array}$ \\
\hline
\end{tabular}

Notes - This table replicates Online Appendix Table 5 except that it replaces the dependent variable outcome of total payouts with the outcome of dividends only. 


\section{ONLINE APPENDIX FIGURE 1 Industry and Size Distribution of the U.S. Population of Corporations}

(a) Industry

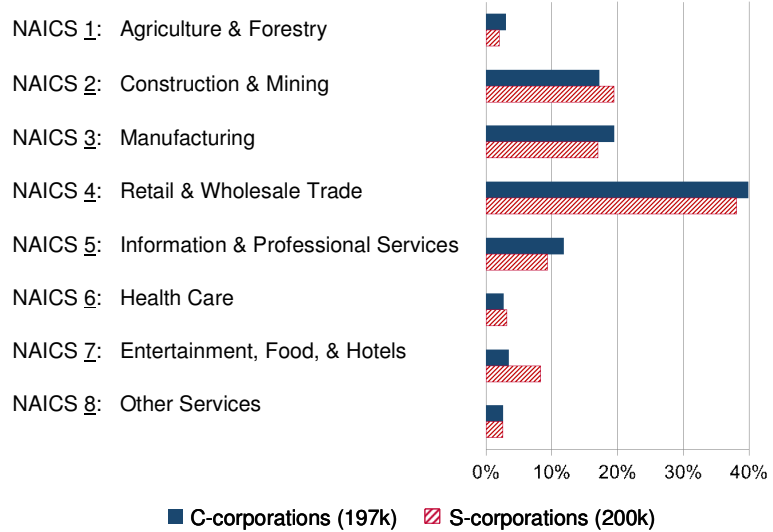

C-corporations (197k) \S-corporations (200k)

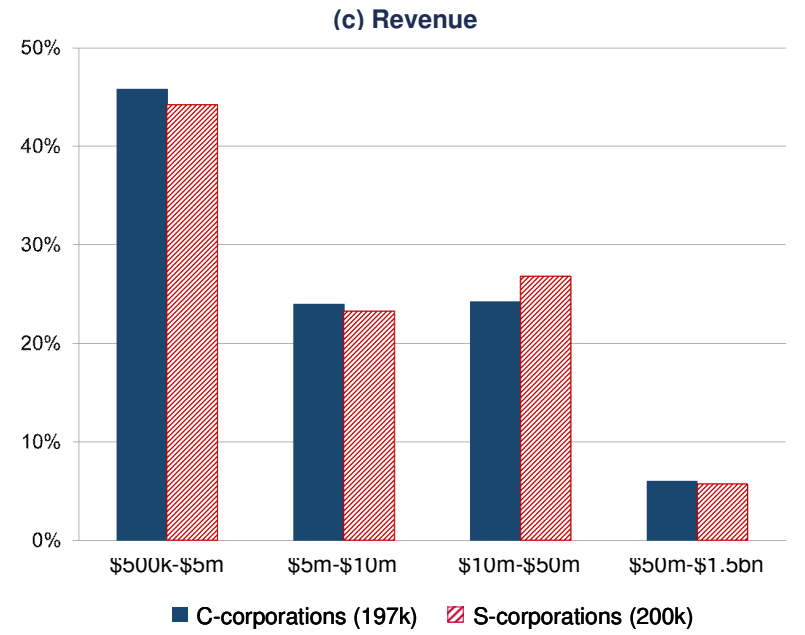

(b) Narrow Industry Within the Most Common 3-Digit NAICS Category

NAICS 4231: Motor Vehicle Supplies

NAICS 4232: Furniture

NAICS 423ㅁ: Lumber

NAICS 4234: Professional \& Commercial Supplies

NAICS 4235: Metal and Mineral Supplies

NAICS 4236: Electrical Supplies

NAICS 4237: Hardware, Plumbing, \& Heating Supplies

NAICS 423요: Machinery Supplies

NAICS 4239: Sports, Toys, and Jewelry Supplies

C-corporations (12k) $\square$ S-corporations (12k)

(d) Example of Operating in the Same Local Markets

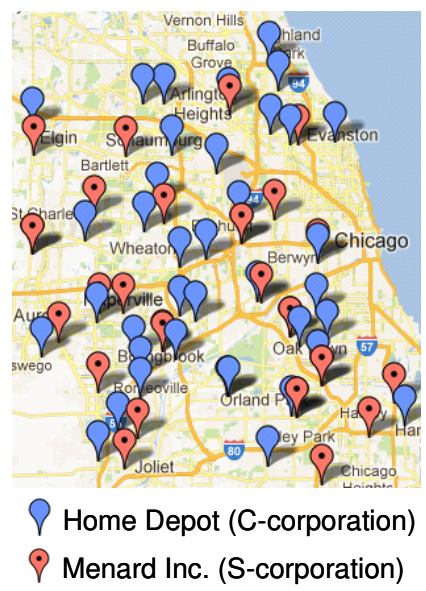

Notes: This figure plots the U.S. population distribution of C-corporations and S-corporations across broad (1-digit NAICS) industry categories, within the most numerous narrow (3-digit NAICS) industry category, and revenue bins. Each graphs's bars sum to $100 \%$ within corporation type. The sample underlying panels (a)-(c) comprises the universe of corporate income tax returns from tax year 2002 that satisfy the size and industry restrictions applied to the paper's main sample: assets between $\$ 1$ million and \$1 billion, revenue between \$500,000 and \$1.5 billion, and any industry other than finance and utilities. These full-population data were drawn from unedited population data at the IRS; these data lack several of the variables necessary for this paper's analysis and so are used only for this figure. Panel (d) illustrates a particular C-corporation and S-corporation operating at similar scale in the same narrow industry in the same local market (suburban Chicago) by plotting their store locations; tax data were not used in any way to construct this panel. Home Depot, Inc., the largest U.S. home improvement retailer, is a publicly-traded corporation and is thus a publicly-known C-corporation. Menard Inc., the third-largest U.S. home improvement retailer, is a pubicly-known S-corporation from a 2003 press story

(http://www.insidemilwaukee.com/Article/242011-BigMoney). Store locations were derived from Google Maps. 